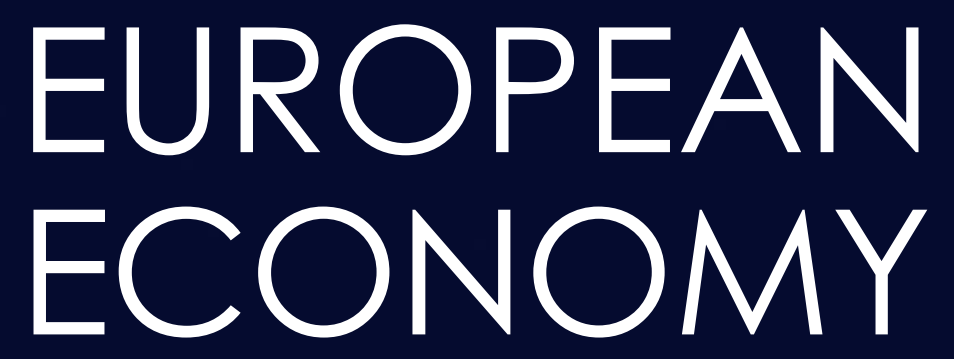

Economic Papers 383| August 2009

\title{
Lessons for China from financial liberalization in Scandinavia
}

Hongyi Chen, Lars Jonung and Olaf Unteroberdoerster

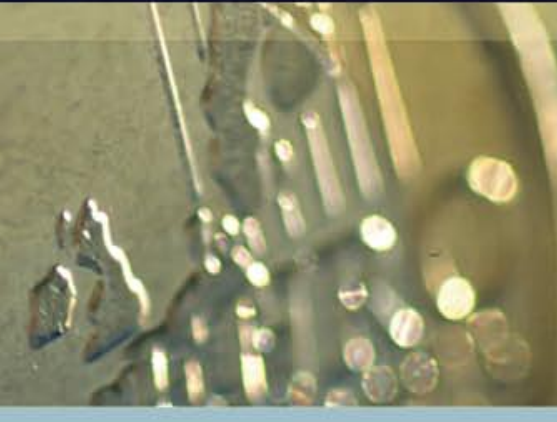


Economic Papers are written by the Staff of the Directorate-General for Economic and Financial Affairs, or by experts working in association with them. The Papers are intended to increase awareness of the technical work being done by staff and to seek comments and suggestions for further analysis. The views expressed are the author's alone and do not necessarily correspond to those of the European Commission. Comments and enquiries should be addressed to:

European Commission

Directorate-General for Economic and Financial Affairs

Publications

B-1049 Brussels

Belgium

E-mail: Ecfin-Info@ec.europa.eu

This paper exists in English only and can be downloaded from the website http://ec.europa.eu/economy finance/publications

A great deal of additional information is available on the Internet. It can be accessed through the Europa server (http://europa.eu )

KC-AI-09-383-EN-N

ISSN $1725-3187$

ISBN 978-92-79-11194-5

DOI $10.2765 / 39780$

(C) European Communities, 2009 


\title{
Lessons for China from financial liberalization in Scandinavia
}

\author{
Hongyi Chen, HKIMR, Hong Kong \\ Lars Jonung, DG ECFIN, European Commission, Brussels \\ Olaf Unteroberdoerster, IMF, Washington DC
}

July 17, 2009

Abstract: This report identifies a set of policy lessons for China today from the experience of financial deregulation, financial crisis and recovery in Scandinavia during the period 19852000. Although there are considerable differences between the huge Chinese economy and the small Nordic countries, there are enough similarities to make lesson-drawing a worthwhile exercise. Based on the Scandinavian experience and the added complexity of China's status as a transition economy, financial reforms should strike a proper balance between being gradual (to avoid costly mistakes) and substantive (to secure efficiency gains in the longer term) with due consideration being given to initial conditions concerning regulation, taxes and exchange rate arrangements. A well managed process of financial deregulation requires that policymakers and market participants fully understand the interlinkages between financial reforms and the rest of the economy. In addition, the supervisory and management systems in the financial sector should move in step with the liberalization process.

Key words: Financial liberalization, financial crisis, transition, financial regulation, banking, boom-bust, China, Scandinavia, the Nordics.

JEL classification: E52, E58, F31, F32, G01, G21, G28, G32, P52.

Email address: Lars.Jonung@ec.europa.eu

Please note: The views expressed here are those of the authors, not of the institutions they are associated with. 
Introduction

1. China's financial system. An overview

1.1 The domestic system

1.2 The external dimension

2. Financial liberalization in China

2.1 Objectives

2.2 Risks

2.3 Towards a new balance?

3. Financial liberalization, crisis and recovery in Scandinavia

3.1 The financial system and economic policies prior to financial liberalization

3.2 Financial liberalization and boom-bust in Finland, Norway and Sweden

3.3 The exception - the case of Denmark

3.4 The long-run effects of financial integration

4. The case for learning lessons

4.1 Differences between the Nordics and China

4.2 Similarities between the Nordic countries and China

4.3 The case for learning lessons for China

5. Lessons for China from Scandinavia

5.1. Lesson 1: The dangers of financial ignorance

5.2. Lesson 2: The importance of sequencing reforms to avoid pro-cyclicality

5.3. Lesson 3: The limits of micro-prudential financial supervision

5.4. Lesson 4: The benefits of a flexible and cautious approach

5.5. Lesson 5: Financial liberalization can lead to costly crises, but it does not have to

5.6. Lesson 6: Financial liberalization has long-run benefits

6. Conclusions

References

Box 1

Tables

Figures 


\section{Lessons for China from financial liberalization in Scandinavia}

\section{Introduction $^{1}$}

The current financial crisis has contributed to an interest in the issue of the financial liberalization of China. According to one view, the financial underdevelopment of China is one factor behind the present global imbalances. ${ }^{2}$ These, in turn, have fuelled the ongoing global financial turmoil. Thus, once China gets a modern and open financial system, global imbalances will be reduced. Consequently, part of the solution to the present crisis may be found in the financial deregulation and opening of China.

China is in fact already involved in a process of financial liberalization as part of the opening of the Chinese economy towards the rest of the world. However, the experience of financial deregulation in many countries suggests that the road towards financial globalization can be a risky, indeed a dangerous one. True, there are substantial long-run benefits from a marketbased and globally integrated financial system, but there are also potentially extremely high short-run costs, both economic and political, associated with the transition from a financially underdeveloped and closed economy to a financially open, "globalized" economy. These short-run costs of adjustment should also be compared to the costs of maintaining a financially repressed system - a comparison that is easily forgotten. The status quo is a costly option too.

History suggests that a retreat into financial autarchy in the future cannot be ruled out. ${ }^{3} \mathrm{~A}$ deep depression, war, civil unrest, and/or economic nationalism may arrest the process of financial globalization. However, we are of the opinion that the world economy will remain

\footnotetext{
${ }^{1}$ We are indebted to Moreno Bertoldi, Nigel Chalk, Emil Ems, Hans Genberg, Ulrich Jochheim, Göran Lind and seminar participants at HKIMR for comments. Kenneth Chow at HKIMR and Eulalia Claros Gimeno at DG ECFIN have helped us with data collection. We have benefitted from excellent editorial comments by Douglas Jenks.

${ }^{2}$ See among others Caballero, Farhi and Gourinchas (2008), Blanchard, Giavazza and Sa (2005) and Cooper (2008). Ju and Wei (2007) provide a model on how an inefficient domestic financial system combined with weak corporate governance and a system of weak property rights can result in a bypass effect of simultaneous FDI inflows and financial capital outflows, a feature shared by many developing countries including China today. ${ }^{3}$ See, for example, James (2001) on the global experience of the 1930s. For a current appraisal, see Kose et al (2006)
} 
financially open, in spite of signs pointing the opposite way during the present global financial crisis, and that China will continue to move towards a financially more open system in the foreseeable future.

Thus, China may benefit from the experience - or more precisely from the policy lessons - of other countries, after taking due account of relevant differences in time, institutional structure country characteristics. The challenge is to identify the relevant lessons for China from countries that have undergone financial liberalization.

The aim of this report is to identify a set of policy lessons that are deemed to be relevant for China today from the experience of financial deregulation, and the ensuing financial crisis and recovery in Scandinavia during the period 1985-2000.

The Scandinavian countries or the Nordics - that is Denmark, Finland, Norway and Sweden may not be the first case of financial liberalization and financial crisis that spring to the minds of policy-makers when they are searching for lessons that are relevant for China at the present time. The Nordics are small, advanced market economies and welfare states, with a history of stable political and legal institutions, and with well-developed commercial banking systems that have their roots in the $19^{\text {th }}$ century - open societies with some of the highest standards of living in the world today.

Can these countries really hold lessons for China, one of the biggest countries in the world, far less developed, without a modern social security system, lacking a firm legal infrastructure, with large state-owned banks, and a dormant financial system: in short,- a country in transition from a socialist mode to a market economy?

In answer to that question we are inclined to give a firm "yes". The Nordic experience is worth citing for many reasons. First, China today and the Nordic countries before liberalization share a critical mass of common features: a bank-dominated financial system, strong credit controls, exchange (capital account) controls, lack of risk management experience and lack of financial knowledge, but open on the current account side. Moreover, three of the four Nordic countries - Finland, Norway and Sweden - were pioneers in financial liberalization in the sense that they engineered sharp boom-bust developments in the late 1980s and early 1990s as a result of a process of financial liberalization that started in the 
mid-1980s, well before the emerging market crises of the late 1990s. The forces of financial deregulation and crisis were clearly exposed by the "big-bang" approach adopted by Finland and Sweden in particular. These forces are of a general nature - they apply across countries with diverse characteristics. ${ }^{4}$

The experience of one of the members of the Nordic quartet, Denmark, illustrates how financial liberalization can be implemented without any major output cost, in sharp contrast to events in Finland, Norway and Sweden. The tradition of openness, transparency and frank public debate in the Nordic countries gives us plenty of data and evidence concerning the process of financial liberalization. In addition, the Nordic countries managed to preserve consensus around the policies adopted to handle the financial crisis, as well as consensus around an open financial system after the financial crisis. As Chinese policy-makers are concerned with keeping social tensions at a minimum, the Nordic record may be of special interest on this front.

The report is organized in the following way. Section 1 gives an overview of the present financial system in China, focusing on the financial underdevelopment of China and its implications for global imbalances. Given the state of China's financial sector, section 2 describes the objectives and risks of financial liberalization in China. Section 3 gives an account of financial liberalization in Scandinavia, first by examining the factors that drove the boom, the bust and the recovery and, secondly, by considering the long-run post-crisis effects of financial opening. In section 4, the case for lesson-drawing is made, looking in more detail at the differences and similarities between the Nordics and China. In section 5, lessons from Scandinavia for China are presented. Section 6 concludes.

\footnotetext{
${ }^{4}$ By now there is a considerable literature on lessons from financial crises; many of them dealing with the record of China's closest neighbours during the Asian crises in 1997-98. To our knowledge, there is no study of the lessons for China from the process of financial liberalization in the Nordic countries.
} 


\section{China's financial system. An overview}

\subsection{The domestic dimension}

Table 1 provides a condensed summary of the key characteristics of the Chinese financial system, such as its market structure and legal and institutional framework. The system remains dominated by a large banking system mostly consisting of state-owned institutions. As of end 2007, bank loans accounted for roughly three quarters of all sources of finance, followed by government bonds (10 percent), corporate bonds ( 8 percent) and equity (7percent). With a domestic credit-to-GDP ratio exceeding 120 percent at end 2007, China's banking system is one of the largest in the world, following decades of relatively steady and rapid growth (Figure 1).

The four large state-owned commercial banks (SOCBs) - the Agricultural Bank of China $(\mathrm{ABC})$, Bank of China (BOC), China Construction Bank (CCB) and Industrial and Commercial Bank of China (ICBC) - dominate China's banking system, accounting for roughly two thirds of all banking system assets, and employing over 1.5 million staff in around 100,000 branches.

Other institutions have a more diverse ownership structure, although government entities in one form or another still play an important role. These include the joint-stock commercial banks (JSCBs), which tend to be part-owned by sub-national governments as well as by foreign and private domestic investors, rural credit cooperatives, and policy banks with a specific development objective. Wholly owned foreign-funded banks have more recently begun to enter the market with China's opening under the WTO-rules, albeit starting from a very small base (see below).

Given this structure, reforming the SOCBs has been at the core of China's transition towards a market-based financial system. It is worth recalling that the four large SOCBs were created less than three decades ago with the break-up of the monobank system in 1984. Given their legacy, the banks have for a long time continued to focus primarily on allocating credit to state-owned enterprises (SOEs) based on government plans rather than on commercial criteria, 
which has in part been reinforced by the absence or weakness of creditor rights, conferring an advantage on borrowers with implicit or explicit state guarantees. ${ }^{5}$ The first non-state commercial bank was established as recently as in 1996.

As a result the system has produced a large burden of non-performing loans, which has led to several attempts at recapitalization and bank reform. ${ }^{6}$ The most recent major initiative to enhance banking system efficiency started in late 2003 when the government announced the recapitalization of two major SOCBs in return for changes in the legal structure, corporate governance and risk management, paving the way for strategic foreign investors and eventual listing on the Hong Kong SAR stock exchange. ${ }^{7}$

In parallel with bank restructuring, efforts have been made to improve the legal and supervisory framework. In April 2003, the China Banking Regulatory Commission (CBRC) was established to allow an approach more focused on supervision objectives and ongoing banking system reform, while the People's Bank of China (PBOC) - hitherto the supervisor was to further develop monetary policy, including by placing increased reliance on marketoriented instruments. ${ }^{8}$ In addition, the authorities gradually introduced a bank solvency framework based on BIS standards, as well as an international best practice in accounting and classification standards. A gradual widening or removal of floors and ceilings for interest rates since 1996 has fostered greater commercial orientation among banks.

Beyond the banking system, the launch of a short-term bond market and a non-tradable share reform in 2005 were key developments in promoting more balanced growth of the financial system. These followed the creation of the China Securities Regulatory Commission (CSRC) and the opening of the Shanghai and Shenzhen stock markets in 1990. Yet, notwithstanding the stock market boom in 2007, China's broader financial system remains underdeveloped, lacking adequate institutional structures such as rating agencies, accounting and audit bodies, and the information and legal systems which are necessary to ensure a high degree of transparency and disclosure standards. ${ }^{9}$

\footnotetext{
${ }^{5}$ A bankruptcy law was first adopted in 1998.

${ }^{6}$ Hope and $\mathrm{Hu}$ (2007) provide a detailed chronology of China's banking reform.

${ }^{7}$ See Podpiera (2006) for details.

${ }^{8}$ See Barnett (2004).

${ }^{9}$ Hope and $\mathrm{Hu}$ (2007).
} 


\subsection{The external dimension}

The large size and steady growth of China's banking system in part reflects a combination of high household savings rates, which in itself is likely to be the result of an underdeveloped and unbalanced financial system, and capital account restrictions that limit cross-border flows of capital, and reduce foreign competition and overseas investment opportunities. While bank deposits remain the main savings vehicle within China, access to foreign instruments is limited through the Qualified Domestic Institutional Investor scheme (QDII). However, despite its recent expansion to include equities, the QDII scheme continues to play a fairly limited role, with only half of the approved total of US\$64 billion invested - equivalent to about 1 percent of savings deposits. ${ }^{10}$ In addition, a tightly managed exchange rate has hampered the development of instruments and a market for managing and hedging currency risks. $^{11}$

Against this background, opening commitments under the WTO entry in 2006 and the approval of strategic direct investments in SOCBs by foreign banks have been the main external avenues of promoting financial sector reform in recent years. By now, except for the $\mathrm{ABC}$, all large SOCBs have major foreign financial institutions as investors after successfully completing initial public offerings, some of which were among the largest in global banking history. ${ }^{12}$ The objective of these partnerships is to enhance the efficiency of the banking system at large by enabling knowledge transfer, greater financial innovation and stronger corporate governance, including risk control, into key institutions.

Foreign banks are also directly increasing their branch network, albeit from a small base. For instance, under the Closer Economic Partnership Agreement (CEPA) with Hong Kong SAR, aggregate exposure of Hong Kong SAR banks to non-bank Mainland entities increased to HK\$891 billion (US\$110 billion) in the year ending March 2008.

\footnotetext{
${ }^{10}$ Until October 2007 investment from QDII funds was limited to fixed-income instruments, resulting in little public interest given interest differentials in favour of the Mainland and renminbi appreciation expectations. Sharply negative returns since then, reflecting the stock market decline, are widely considered the major reason why the uptake of QDII quotas has been sluggish.

${ }^{11}$ Until July 25, 2005, the renminbi was pegged to the U.S. dollar. Currently the exchange rate regime is classified as a "crawling peg".

${ }^{12}$ These include for (1) ICBC: Goldman Sachs, Allianz and American Express; (2) BOC: Royal Bank of Scotland, UBS, and Temasek; and (3) CCB: Bank of America and Temasek. Through IPOs in Hong Kong SAR these three banks combined raised about US\$ 41.3 billion in 2005 and 2006, respectively. For further details see Podpiera (2006).
} 
A most striking feature of China's integration into the global economy has been the large build-up in official foreign reserves during the past 15 years, rising more than tenfold from about US\$150 billion in 1995 - at that time about the same level as for the Scandinavian countries combined (Figure 2). At nearly US\$2 trillion, China today is by far the single largest holder of international reserves, owning more than the next four largest holders combined. ${ }^{13}$ According to US Statistics, China accounts for about 24 percent of US Treasury bills and bonds held by foreigners at end 2008 (and 40 percent of the increase since 2005). This mainly accrues to the PBC and other government agencies tasked with the management of China's official reserves. The build-up of reserves is mainly due to large and rising current account surpluses (reaching 11 percent of GDP in 2007), and foreign direct investment and other long-term capital inflows attracted by China's rapidly growing economy. Periodically, there have also been inflows of hot money, fuelled by expectations of a revaluation of the renminbi (RMB), for example around the time of the exit from the peg to the US dollar in July 2005.

The massive accumulation of reserves, which is unprecedented by historical and crosscountry standards, highlights China's role in the build-up of global imbalances, whereby surplus countries like China are a net exporter both of goods and services and of capital to finance deficit countries, such as the United States. The underlying sources of the imbalances, in particular the question of whether and to what extent exchange rate policies have played a role, continue to be a controversial issue, amongst both policy-makers and researchers. ${ }^{14}$

There is a consensus that structural reforms, including bank reform and financial liberalization, can play an important role in affecting savings and investment behaviour and thereby help achieve an orderly resolution of global imbalances. ${ }^{15}$ In addition, Chinese banks have been recapitalized with official reserves in past restructuring exercises, suggesting that reserves may also act as a buffer to cope with reform failures in the future. As such, China's official

\footnotetext{
${ }^{13}$ As of January 2009, these include: Japan (US\$1 trillion); Russia (US\$ 387 billion); Taiwan Province of China (US\$ 293 billion); and India (US\$ 249 billion).

${ }^{14}$ For an overview of approaches and a range of estimates for measuring equilibrium values of the real exchange rate in the case of China, see for example Li and Dunaway (2005) and Dunaway, Leigh and Li (2006). For the debate on the Chinese policy of reserve accumulation, see among others Bussière and Mehl (2008), Cappiello et al (2008), Haltmaier et al (2007) and McKinnon and Schnabl (2008).

${ }^{15}$ Accelerating financial sector reform has been a key policy commitment by China under the IMF multilateral consultation on global imbalances. For an analysis of the role of banking sector reform and financial market development on household consumption and firm investment in China see, for example, Aziz (2006), Aziz and Cui (2007), and, in particular on the interplay with enterprise reform, Dollar and Wei (2007). See also Farrell et al (2006).
} 
reserves highlight the massive footprint that the lack of financial liberalization and of other structural reforms may leave on the global economy.

To summarize, China's financial system has undergone significant reform since the break-up of the monobank system less than three decades ago. The culture of independent and commercial decision-making is young at best, especially when compared with the century-old tradition of commercial banking in Scandinavia and other advanced market economies.

At the same time, progress in overcoming a legacy of state ownership and credit allocation to state-owned enterprises, and in building the legal, supervisory and macroeconomic framework necessary for setting the appropriate risk management incentives, has been gradual. In this context, Ng (2007) characterized China's transition to a market-oriented banking sector and, by implication, to a market-based financial system by using the famous aphorism of Deng Xiaoping "crossing the river by touching the stones".

Nevertheless, this gradual approach, combined with stable macroeconomic growth and capital controls shielding the system from foreign competition and cross-border capital flows, has contributed to confidence in the banking system. The steady rise of bank intermediation in China to some of the highest levels worldwide stands in marked contrast to the experience in the transition economies of Eastern and Central Europe, where periods of sharp retrenchment and disintermediation - in other words financial tensions and banking crises - has been a common aspect of financial reform experience. ${ }^{16}$

\section{Financial liberalization in China}

\subsection{Objectives}

Financial liberalization in China has to be put in the context of overall reform towards a market-based economy. This implies, as shown by the experience of many transition economies, that reforms in the financial sector must be tackled in concert with reforms in

\footnotetext{
${ }^{16}$ For an in depth review of SOCB reforms in the transition economies of Eastern Europe and the CIS countries see for example Sherif, Borish and Gross (2003) and Tang, Zoli and Klytchnikova (2000). By contrast, some Asian transition economies, notably Vietnam, have maintained a path of steadily rising intermediation levels
} 
other areas, notably in the corporate sector, including state-owned enterprises, in the legal and institutional framework, and at the macroeconomic level, including monetary and exchange rate policies. Given their dominance in the financial system, reforms of the large SOCBs have been put at the core of China's strategy to improve the intermediation of its large private sector savings. However, mutually reinforcing reforms at the macroeconomic level are also on the agenda, such as reforms towards a more independent, market-based monetary and exchange rate policy, and capital account liberalization.

Unlike most other transition economies, China's experience so far has been unique in that domestic macroeconomic stability and growth have been maintained throughout the reform process. China's economic weight in the world makes it "too big to fail"; while a large and growing current account surplus - or savings-investment imbalance - continues to put additional pressures on its major trading partners.

Maintaining stability, and at the same time improving allocative efficiency through the liberalization process, are thus the overarching reform objectives, both from a Chinese and from a global perspective. Moreover, financial liberalization can also play an important role in rebalancing China's growth and reducing global imbalances. As banks in China increasingly operate on a commercial basis, and as the capital market develops further, the efficiency of investments is likely to improve, while better access for households to both credit and savings instruments would boost consumption and bring down the high savings rate.

\subsection{Risks}

The Chinese authorities have sought stability in the reform process primarily by adopting a gradual approach. Yet, while this has been reasonably successful so far, gradualism is not without risks. Along with the gradual reforms, there has been a build-up in domestic and external imbalances that result from the still artificially low cost of capital - favoured by a lack of competition for funds among the dominant SOCBs - of energy and land, and from policies that favor the export sector. At the same time, a rigid exchange-rate regime has hampered the effectiveness of monetary policy in curbing investment and credit growth. On the external front, pressures are mounting too, as China's growing current account surplus has 
become so large relative to the rest of the world that it is increasing the risk of a protectionist backlash, and thereby threatening global trade and investment.

Moving on to the core of the financial reforms, another risk is that the gradual approach to the reform of SOCBs is not effective in changing their behaviour. So far, the SOCBs have strengthened their balance sheets with the help of public recapitalization funds, but without prior demonstration of improvements in key operational areas, particularly risk management. Non-performing loans have been successfully reduced, but this is merely a backward looking indicator. What would happen to non-performing loans if the economy were to slow after years of very rapid growth, or if the export sector were to falter - as is currently the case? Indeed, Podpiera (2006) demonstrates that lending behaviour of SOCBs has changed little at best, and in particular that the pricing of credit risks remains undifferentiated, while lending appears to be mainly driven by the availability of funds (i.e. savings deposits) and does not take enterprise performance into account. ${ }^{17}$

Given the need for a comprehensive approach to reform, there is also the risk of inconsistencies between reform areas. For example, without further reform of state-owned enterprises and the corporate sector at large, more accountable risk managers at banks may actually shift lending away from the private sector, given the lack of guarantees and reliable accounting data.

Greater autonomy of banks in relation to price credit risks will require additional interest rate liberalization. Incentives for developing exchange risk tools will depend on the degree of exchange rate liberalization. In turn, the awareness of exchange rate risks and experience in managing them will influence the costs and benefits from further capital account liberalization. In this context, Prasad et al. (2005) argue that the liberalization of capital flows should be sequenced in a manner that reinforces domestic financial liberalization and allows for learning to manage additional risks, making greater exchange rate flexibility a pre-requisite for fully opening the capital account.

\footnotetext{
${ }^{17}$ As the data cover the period 1997-2004, it may be difficult to find clear evidence of changed behaviour in the early stages of the reforms.
} 


\subsection{Towards a new balance?}

Further financial reform and liberalization strike us as inevitable, as China's transition to a market-based economy is far from completed. Yet, given the complexity of the challenge arising from the intricate interdependencies with progress in other reform areas and the need for maintaining stability, the ongoing reforms have to strike an appropriate balance between being gradual and being substantive. This will afford policy-makers time to learn and a margin of (inevitable) error, as any reform - even in advanced economies - is fraught with unintended consequences, which is - as we shall see - a key lesson from the Scandinavian liberalization experience. It will also enable the reforms in different areas to become mutually reinforcing and to sustain the momentum of reform.

\section{Financial liberalization, crisis and recovery in Scandinavia ${ }^{18}$}

\subsection{The financial system and economic policies prior to financial liberalization}

The policy framework and the macroeconomic policies that evolved in Finland, Norway and Sweden after World War II crucially influenced developments during and after financial liberalization. The financial system of Finland, Norway and Sweden in 1985, roughly at the start of the process of financial liberalization, is presented in stylized form in Table 1. The financial system was bank-based, with banks - both commercial and savings banks - having the major role as financial intermediaries. The government held a strong position in the governance of the financial system, determining via the central bank the allocation of credit and the level of interest rates.

Finland, Norway and Sweden became early members of the Bretton Woods system, pegging their exchange rates to the US dollar. All three countries maintained far-reaching capital account or exchange controls. The control of the external flow of capital was a major pillar for post-war stabilization policies, since it isolated Finland, Norway and Sweden from international financial developments, thus allowing far-reaching domestic interventionist and selective monetary and fiscal policies. The capital account controls served as the wall behind

\footnotetext{
${ }^{18}$ This section on the Scandinavian or Nordic record rests primarily on Englund and Vihriälä (2009), Jonung, Kiander and Vartia (2009), Steigum (2009) and Vastrup (2009).
} 
which the central banks determined the rate of interest as well as the distribution and size of capital flows within the domestic economies according to political priorities.

Monetary policy was used to subsidize those sectors of the economy that the government wanted to support with low interest rates and an ample supply of credit. Banking became an almost risk-free enterprise in this system. Since nominal interest rates were kept below market-clearing levels by means of regulations, the demand for credit remained greater than the available supply, which was rationed by the monetary authorities. As a result, households and firms in the private sector remained permanently credit constrained, with the exception of those sectors that obtained finance through credit allocation by the central bank.

International financial integration contributed to the downfall of the Bretton Woods system in the early 1970s. Nevertheless, after its demise, both capital account controls and internal financial controls remained in force in Finland, Norway and Sweden, while their exchange rates remained pegged.

In the 1970s, full employment emerged as a major policy goal. One reason was the strong political position of labour parties and labour unions; another reason was the dominance of Keynesian policy thinking. The goal of full employment in the face of the two oil crises (OPEC I and II) contributed to expansionary fiscal and monetary policies in the form of several devaluations of the pegged exchange rates to maintain aggregate demand. The devaluations created the adjustment of real wages that was required in order to maintain full employment during the 1970s and early 1980s. Sweden took a leading role. When Sweden devalued, its Nordic neighbours commonly felt forced to follow suit in order to stay competitive.

Denmark, however, did not follow Sweden's huge devaluation in October 1982. Instead, it kept its exchange rate unchanged as part of a hard currency policy that has remained in force since that time. In fact, the Danish decision not to follow the Swedish devaluation was a crucial one, as it set Denmark off on a trajectory that was different from that of Finland, Norway and Sweden later in the 1990s. ${ }^{19}$ Norway did not devalue at this time either.

\footnotetext{
${ }^{19}$ See Schaumann (1993).
} 
As a result of the policy of accommodation, high inflation and high inflationary expectations became deeply rooted in the 1970s and early 1980s. Real after-tax interest rates turned negative due to the combination of regulation of nominal interest rates, high inflation and a tax system that allowed substantial tax deductions for private individuals for the payment of interest rates on housing loans.

To sum up, prior to the financial crisis of the 1990s, Finland, Norway and Sweden were seen as small, rich, welfare states, immune to the high unemployment that plagued large parts of Western Europe. To many, they appeared to be successful models for economic policy based on consensus within society. Few understood that the macroeconomic policy regimes of the three countries rested on a system of far-reaching capital account regulations which isolated them from the rest of the world.

\subsection{Financial liberalization and boom-bust in Finland, Norway and Sweden}

Financial liberalization and the boom. In the early 1980s, the financial systems of Finland, Norway and Sweden underwent major deregulation, starting with Norway. The abolition of domestic and external controls was a gradual process, which took place over several years. It is difficult to identify one single comprehensive measure or indicator of the liberalization process. The three Nordic countries opened their capital accounts fully at the end of the 1980s following domestic liberalization. ${ }^{20}$

Financial liberalization had a fundamental effect on the incentives of lenders and borrowers. Bank lending could now be expanded free of any binding regulatory restrictions. Banks entered into fierce competition for market shares. They did so primarily by expanding loans to old and new customers rather than by reducing spreads between lending rates and deposit rates (Figure 9). However, on a risk-adjusted basis, the aggressive growth into new market segments may well have entailed a substantial narrowing of the banks' interest rate margins. The lending boom that started in the mid-1980s channelled credit to the asset markets, causing rising asset prices. Asset prices grew more rapidly than consumer prices. Rising asset prices in turn formed the basis for rising collateral values, further fuelling credit expansion as part of a cumulative process.

\footnotetext{
${ }^{20}$ See Figure 3 in Jonung (2008).
} 
The private sector, previously strongly rationed in the credit market, made use of the growth in asset prices as collateral for absorbing more debt. As banks and other financial institutions increased their lending, in particular for property purchases, the volume of bank loans as a percentage of GDP rose markedly in the Nordic countries (Figure 3).

In this process, the rate of inflation and inflation expectations increased further. Real after-tax interest rates (adjusted for inflation expectations) were negative or close to zero for companies and households, which bolstered their demand for loans (Figure 4). The financial system experienced a period of extreme expansion. The result of the new incentive structure was a build-up, as became apparent later, of massive over-indebtedness and corresponding overlending within the financial system in the Finnish, Norwegian and Swedish economies.

The macroeconomic outcome was a strong boom, first in Norway, and later in Finland and Sweden in 1988-89, as Norway had started its financial deregulation a few years before Finland and Sweden. The boom was characterized by overfull employment, rising consumption and falling savings. The current account worsened as export performance weakened, sharply in Norway - primarily as a result of falling oil prices around 1986 - and more slowly in Finland and Sweden. The national budgets turned into surplus during the peak on the back of property- and capital-based taxes, as well as tax revenues related to booming consumption and high nominal wage growth. Public consumption and public expenditures also grew rapidly during the boom. Strong international expansion in the second half of the 1980s compounded the overheating of the Nordic economies, in particular in Finland and Sweden.

At this point in time, judging from policy documents, from interviews after the crisis with policy-makers and from the memoirs of ministers of finance and central bankers, the policymakers did not recognise the risks inherent in the process of financial integration. Initially they were unwilling to change either monetary or fiscal policy. Monetary policy was confined to safeguarding the pegged exchange rate, with the exception of the devaluation of the Norwegian currency in 1986 following the decline in the price of oil (OPEC III). Finland made a failed attempt to dampen its boom in 1989 by revaluing the markka.

All in all, financial deregulation was the key to the birth of the strong boom phase in all three countries. The deregulation was pushed through without any serious public debate. It was not 
presented as part of a larger policy programme, but rather as a series of technical changes. There was no common knowledge of the consequences of international financial integration, although a few voices did warn of the dangers. ${ }^{21}$

Rising real interest rates and bust. The boom in the real economy was eventually halted and transformed into a bust by a combination of factors. Real interest rates rose internationally as a result of German monetary policy becoming more contractionary after German reunification, putting strong upward pressure on Nordic interest rates. In addition, monetary policy was made more restrictive by the pegging of the Finnish, Norwegian and Swedish currencies to the ecu in 1990-91. Previously, the exchange rates had been linked to a basket of currencies. Finnish and Swedish domestic interest rates rose strongly above those of Germany when attempts were made to defend the pegged exchange rate against recurring speculative attacks in 1989-92. ${ }^{22}$ As the Finnish and Swedish currencies became overvalued because of the boom, the export sector encountered growing problems. For Finland, the collapse of trade with the Soviet Union contributed to domestic imbalances.

Various policy measures increased the real after-tax interest rate. In Finland, stepwise limitations in the tax deductibility of mortgage rates in the early 1990s raised the after-tax cost of servicing debt. The far-reaching Swedish tax reform of 1990-91, which lowered marginal taxes significantly, contributed to higher real after-tax interest rates by reducing the tax deductibility of mortgage rates. In this way, borrowing became less attractive, while private savings grew more attractive. A rapid and not altogether expected decline in the rate of consumer price inflation in 1990-92 also contributed to the sharp rise in real interest rates in Finland and Sweden (Figure 4).

The big increase in the real rate of interest had profound effects on the balance sheets of the private sector. Asset price deflation surfaced when the value of real assets was reduced by the rise in real interest rates. Balance sheets turned fragile when asset values - primarily property prices - fell below collateral values. At the same time, the nominal values of debts remained unchanged. The losses of wealth became enormous, forcing an adjustment of portfolios which

\footnotetext{
${ }^{21}$ On this point see Jonung, Kiander and Vartia (2009) for the record of Finland and Sweden and Steigum (2009) for the case of Norway.

${ }^{22}$ See Jonung, Kiander and Vartia (2009).
} 
led to lower private consumption and investments and to a strong increase in private savings. ${ }^{23}$

The harder households and companies tried to improve their wealth position by selling assets, the deeper the crisis became. The number of bankruptcies increased dramatically. Asset price deflation showed a cumulative tendency. The selling off of property forced down property prices which, in turn, triggered new sales. Stock market prices tumbled, in particular those of firms engaged in the financial sector, real estate and construction. The crisis turned into a systemic financial crisis - a new experience for the Nordic countries in the post-World War II period. $^{24}$

Investments plummeted, most rapidly within the construction sector. Real GDP growth fell sharply. The Finnish and Swedish economies contracted in the early 1990s (Figure 5). Unemployment soared. Tax revenues fell and public expenditure rose. In Finland and Sweden, the government budget deficit - and thus the ratio of government debt to GDP - increased dramatically, particularly in Finland. Norway, on the other hand, did not experience any rise in government debt thanks to large government revenues from oil and gas extraction.

In 1992, the financial system of all the three countries was rocked when their currencies were exposed to major speculative attacks. An international currency crisis erupted in September 1992. The domestic banking crisis quickly turned into a currency crisis as well. The Finnish markka was floated in September 1992. The Swedish krona followed suit two months later, in November 1992. The Norwegian krone was taken off its pegged rate in December 1992.

Recovery. The floating of the currencies in the autumn of 1992, with ensuing depreciation and receding domestic interest rates, arrested the downturn of the Finnish, Norwegian and Swedish economies. An upturn commenced in all three countries in the following year and lasted for several years, although unemployment remained high for a long time. Unemployment did not start to decline until the mid-1990s, from which point it fell steadily. The main engine behind the recovery was an impressive growth in exports. Export shares rose significantly in all three countries, most markedly in Finland and Sweden.

\footnotetext{
${ }^{23}$ See Jonung, Kiander and Vartia (2009) for the balance sheet adjustment in Finland and Sweden and Steigum (2009) in Norway.

${ }^{24}$ For a summary of the balance sheet approach to financial crisis, see Allen et al (2002).
} 
The rate of inflation stayed contained, at around two percent per annum throughout the period 1995-2000. Wage and price increases remained at surprisingly low levels given the size of the depreciation of the currencies. High unemployment contributed to low wage increases. Fiscal policy was directed towards lowering the budget deficits. The three countries eventually emerged among the strongest in Europe in terms of their budgetary position, although the Norwegian case is a special one due to its revenues from the energy sector.

The recovery after the boom-bust cycle turned out to be a lengthy one - it lasted at least until the downturn in worldwide economic activity around 2001. Finnish and Swedish growth rates in the early 2000 s remained above the EU average however.

\subsection{The exception - the case of Denmark}

Denmark avoided the economy-wide systemic financial crisis that hit Finland, Norway and Sweden in the late 1980s and early 1990s. A combination of macroeconomic and microeconomic factors contributed to Denmark being spared the Nordic boom-bust pattern, although substantial problems emerged in both the Danish banking sector and the Danish economy. ${ }^{25}$

In the early 1980s, Denmark was facing severe economic problems. Unemployment, inflation and interest rates were high; large budget deficits prevailed and deficits on the current account were large. In addition, policy-makers faced a credibility problem as the Danish krone had been devalued several times. In the midst of these problems, on 9 September 1982, Denmark announced the adoption of a hard currency policy by tying the krone to the ecu, a basket of European currencies. A month later, when Sweden devalued by 16 percent on October 8, Denmark decided not to follow suit, instead remaining in the European Monetary System (EMS) of pegged exchange rates where the German mark acted as the anchor of the system. Thus, Danish monetary policy was tied to Germany's policy.

The credibility of the Danish currency peg gradually increased: Fiscal policy was tightened in the face of chronic and rising current account deficits. By 1990, this policy gradually wiped out the deficit, turning it into a surplus of 3 percent of GDP in 1993, while Finland and

\footnotetext{
${ }^{25}$ This section is based on Vastrup (2009). See also Callesen et al (2008), Drees and Pazarbasioglu (1998) and Schaumann (1993).
} 
Sweden displayed huge deficits in 1990-93. Following gradual reforms of the labour market and cautious demand management in the second half of the $1990 \mathrm{~s}$, unemployment fell to a level below that of most other European countries.

As a result, the European currency crises in 1992-93 and the short-term deviation by Denmark from the pegged exchange rate regime during this episode did not affect the stability of either the Danish economy or its banking sector. In the long-term perspective, the external orientation of fiscal policy and the strict adherence to a pegged exchange rate for the krone were crucial in bringing about macroeconomic stability in Denmark after the precarious situation in the early 1980s. In contrast to its Nordic neighbours, Denmark managed to create a macroeconomic policy that did not foster a boom-bust cycle, thereby contributing to stable financial and monetary conditions.

Turning to the financial sector, Denmark adopted a more market-oriented approach to the governance of financial markets in the post-World War II period than its Nordic neighbours. Denmark also entered a process of financial liberalization in the 1980s. However, it started from a position where - as early as the 1950s, 1960s and 1970s - Danish financial markets were already more integrated with the international financial markets than was the case in the other Nordic countries. Quantitative and other restrictions on the banking sector (internal liberalization) had already been terminated in 1980-81, prior to domestic deregulation in Finland, Norway and Sweden. Moreover, deregulation was introduced in the midst of a recession. All in all, financial liberalization in Denmark involved less of a change in prevailing conditions than was the case in the other Nordic countries.

The financial position of commercial banks in Denmark deteriorated in the late 1980s. The problems came to a head in 1991-93, when the total losses and loss provisions reached more than 5 percent of GDP. The losses and loss provisions relative to GDP of Danish banks were at the same level as in Norway, although lower than in Finland and Sweden. However, the problems of Danish banks never developed into a systemic banking crisis. ${ }^{26}$ Government support for commercial banks in Denmark stayed at 0.4 percent of GDP, whereas it was 8.1 percent for Finland, 3.6 percent for Norway and 4.1 percent for Sweden. In addition, the

\footnotetext{
${ }^{26}$ This is also seen from the banking crisis database compiled by Caprio et al (2005), covering banking crisis since the late 1970s. This database ranks the banking crises of Finland, Norway and Sweden as systemic crises while the Danish banking record is not classified as a systemic crisis.
} 
Danish banking system was able to absorb the losses and the loss provisions by itself because Danish banks were better capitalized than the banks of the other Nordic countries. ${ }^{27}$

To sum up, a combination of macroeconomic and structural policies inoculated the Danish economy against the forces that created the boom-bust patterns in Finland, Norway and Sweden in the late 1980s. Denmark adopted a hard currency policy in the early 1980s and managed to maintain this approach despite a number of challenges, including problems within its banking system. That system was well-capitalized and more geared towards financial openness than was the case in the other Nordic countries.

\subsection{The long-run effects of financial integration}

The Nordic financial crisis of the 1990s was a devastating one, as demonstrated in Table 2 which shows the real costs of the major crises that have hit the Nordic economies since the 1870s, using an approach developed by the IMF (in 1998) and extended by Bordo et al. (2001). The loss in real income growth, as defined by the IMF approach, is calculated by taking the sum of the differences between the trend growth rate and the actual growth rate from the start of the crisis until the growth rate returns to trend rate. This is also done for industrial production.

Table 2 shows that the financial crisis of the 1990s, measured as the output loss in percent of GDP, was deepest in Finland (26.4 percent), followed by Sweden (13.0 percent) and Norway (12.4 percent); Denmark did not experience any crisis in the 1990 s.

The same picture emerges when the cost of the crises is estimated in terms of loss of industrial production, although there are two main differences. The crises in Finland and Sweden are close in terms of size (21.4 and 17.0 percent, respectively), while the cost of the crisis in Norway is very small (2.7 percent). As mentioned above, there is no evidence of any crisis in Denmark in the 1990s. Table 2 also shows that the crisis in Norway started earlier than in Finland and Sweden, but did not last as long. The annual loss in Norway is considerably smaller than in Finland and Sweden. ${ }^{28}$

\footnotetext{
${ }^{27}$ See Vastrup (2009).

${ }^{28}$ The cost of the crises of the 1990s in Finland, Norway and Sweden has been calculated in alternative ways by Schwierz (2004, Table 4). He demonstrates that the result is sensitive to the exact method applied and to the
} 
Looking beyond the immediate crisis and its costs to society, it is clear that financial liberalization has profoundly changed the economic landscape in the Nordic countries. These long-run effects have been overshadowed by the dramatic events during the boom-bust cycle. However, once financial markets were opened up, this impacted on a large number of sectors both inside and outside the financial system.

The rules for monetary and fiscal policy-making were reformed. Inflation targets were introduced. Finland entered the euro area in 1999 as part of the process of European monetary and financial integration. The stock markets of Finland and Sweden expanded as part of the process of financial opening and integration. Foreign holdings of domestic stocks showed a rapid rise. Corporate governance changed profoundly once foreign ownership was allowed. Taxation was adjusted to international tax competition. These effects are discussed below. ${ }^{29}$

Effects on the design of stabilization policies. Financial liberalization had a major impact on the stabilization policy regime in Finland, Norway and Sweden. First, the pegged exchange rate regime of the three countries was abolished, as the pegged rate proved to be an inadequate nominal anchor during the process of financial liberalization and the ensuing boom-bust. After the crisis, the pegged rate was replaced by inflation targeting. This monetary policy strategy, founded on openness, accountability and communication through changes in the short-term interest rate set by the central bank, requires the existence of well-functioning financial markets. Thus, financial liberalization and subsequent financial integration created the prerequisites for a new type of monetary policy regime or policy framework that could not have existed in the previous economy, which had been financially closed and heavily regulated, and where short- and long-term interest rates were subject to strict administrative controls.

Second, following the experience of large budget deficits, the institutional framework for fiscal policy making was changed - particularly in Sweden - towards a rule-based policy. The basic idea was to reduce the scope for short-term discretionary fiscal policies by tying the hands of policy-makers. This policy has so far been successful in the sense that the Nordic countries can point to some of the strongest public finances in Europe.

dating of the start and end of the crisis. Still, the loss ranking between Finland, Norway and Sweden remains the same.

${ }^{29}$ See Jonung (2008) on the systemic effects of financial openness. 
Effects on growth: Although improving economic efficiency is the central objective, there is still considerable debate about the growth effects of financial liberalization, given that it is often associated with boom-bust patterns, ending in financial crises and deep recessions with negative growth rates. ${ }^{30}$ The evidence from Scandinavia, which is not commonly referred to in the international debate, throws light on the relationship between financial integration and growth. In short, the Nordic record suggests that financial crises, triggered by a process of financial liberalization, can be extremely costly in the short run in many respects: to society, to taxpayers, to owners of stocks and equities, and to politicians in power. However, such crises can also contribute to high growth for a long period following the recovery (Table 2).

The fiscal cost of the crisis was enormous, as budget deficits and public debt soared when tax revenues declined and government expenditures increased, largely due to the workings of automatic stabilizers. Government support for the financial system ballooned in the short run. The private sector - in particular holders of stocks in banks and other financial institutions was hit by huge wealth losses. The political costs were significant too. Governments in power at the start of the crisis lost popularity and were replaced in subsequent elections. Whether or not the policy-makers in power were the ones who had designed the policies that led to the crisis, the voters held them responsible.

Looking at the long-run consequences of the financial crisis on the growth of the economy during the early 1990s, a more positive picture emerges. The post-crisis growth rates of Finland and Sweden have been high compared to the EU average since 1993 and also compared to the pre-crisis growth pattern of the 1970s and 1980s. There is much to suggest that this improved growth performance is associated with the financial crisis and the subsequent financial integration. ${ }^{31}$

The financial crisis served as a window of opportunity for policy-makers to carry out growthenhancing reforms. In this way, the crisis contributed to the transformation of the Nordic economies, making them more dynamic, releasing Schumpeterian processes and raising their

\footnotetext{
${ }^{30}$ See Henry (2007) and Tornell and Westermann (2005) for recent surveys of the issues involved. Their work deals with middle-income or emerging-market economies, while the Nordic countries are high income economies.

${ }^{31}$ See the evidence discussed in Jonung, Kiander and Vartia (2009).
} 
growth potential. It is likely that the rapid developments in the financial systems of Finland and Sweden impacted positively on the growth potential of the two economies.

Effects on structural policies: Most of the discussion of the immediate impact of financial liberalization and financial integration has focused on the banking system and the financial sector. However, once the cross-border barriers to financial flows had been eliminated in Finland and Sweden, competitive pressure for efficiency-enhancing reform spilled over into areas other than the financial system.

This affected policy areas such as the rules and regulations dealing with foreign ownership of domestic real and financial assets, the taxation of income and wealth in a financially open economy and the design of corporate governance laws. ${ }^{32}$ In Sweden, gift taxes, inheritance taxes and wealth taxes were abolished in the early 2000s in response to the opening of the Swedish financial sector. These are radical changes for a country with a strong egalitarian tradition. Financial integration is thus likely to impact on the distribution of income and wealth. Recent empirical research suggests that periods of financial integration and freely working financial systems in Sweden are associated with growing differences in income and wealth. ${ }^{33}$

To sum up, financial integration following the policy of financial liberalization lent a very powerful impetus to the process of globalization of the Nordic economies, affecting the characteristics of the Nordic or Scandinavian model. ${ }^{34}$ There is much to suggest that this pattern is to a large extent due to the long-run adjustment dynamics created by the financial crisis and by subsequent financial integration.

\section{The case for learning lessons}

In our introduction we asked the question: Can the Nordic experience of financial liberalization really hold lessons for China, given the differences between China and the Nordics? We believe that these differences do not preclude the drawing of lessons per se.

\footnotetext{
${ }^{32}$ For example, financial liberalization impacted strongly on corporate governance in Finland and Sweden. See Ylä-Antilla et al (2005) on the Finnish case and Henrekson and Jakobsson (2005) on the Swedish case.

${ }^{33}$ Roine et al (2008).
} 
Rather they indicate the extent to which policy lessons should be qualified to reflect countryspecific circumstances. Still, we will argue below that it is the similarities that dominate, as China and the Nordic countries share a critical mass of common features. Moreover, the Nordic reform experience holds lessons of a general nature on the dynamics of boom and bust and how to preserve a consensus for reform that are worthwhile for China to consider as it proceeds with financial liberalization.

\subsection{Differences between the Nordics and China}

Size is arguably the main fundamental difference between the Nordics and China. (See Table 3 for some key demographic and economic comparisons between the Nordics and China). By the end of 2007, about 15 percent of the world's population lived in China, more than 70 times the total population of the Nordics as a whole. China's GDP was about 11 percent of the world total, or about four times that of the Nordic countries. China's size means that monitoring and maintaining an orderly and steady reform process is more challenging than in the case of the Nordics. This is further complicated by China's significantly less advanced stage of development and much higher income inequality. The Nordics' per capita income is about 8 times higher than that of China in purchasing power parity terms (Figure 6). In addition, income inequality, in particular between coastal areas and inland provinces, has been rising rapidly in China. ${ }^{35}$ As a result, the risk that the social costs of reform may create social tensions is significantly higher in China than it was in the case of the Nordics. Indeed, a highly risk-averse approach and the fear of economic and social instability on the side of the Chinese authorities are part of the explanation why China's process of financial liberalization has been more gradual than in Finland, Norway and Sweden.

Risks associated with differences in size and stages of development are mitigated by China's more favourable macroeconomic performance in a number of areas. First of all, China's economic growth in the past decade has been high and stable at an average annual rate of nearly 10 percent, much higher than among the Nordics where growth rates ranged between 0 and 4 percent in the early 1980s before financial liberalization (Figure 5). Second, high economic growth in China in recent years has resulted in stronger government revenues and smaller fiscal deficits than among the Nordics. The official government debt figure is only 21

\footnotetext{
${ }^{34}$ The Scandinavian or Nordic model is recently evaluated in Andersen et al (2007) and Calmfors (2007).

${ }^{35}$ Lueth and Syed (2006) provide a detailed cross-country analysis of rising inequality and polarization in Asia.
} 
percent of GDP in China, although contingent liabilities might be large. In the Nordic countries, the budget deficits were large in the late 1970s and early 1980 s due to stimulus spending to combat the effects of two oil crises (Figure 7). Third, as mentioned before, China has the largest foreign reserves in the world, close to US\$2 trillion, more than 170 percent of total imports or nearly seven times its short-term debt, while the Nordic countries as a whole held less than US\$30 billion of foreign reserves in 1985, i.e. 38 percent of total imports (Figure 2). Fourth, China's currency, the renminbi, experienced no depreciation pressure, whereas the currencies in Nordic countries had been depreciating in the early 1980s.

Finally, regarding the financial system, the volume of credit supplied by China's banking system as a percentage of GDP is more than 100 percent, much higher than the ratio for the Nordic countries in early 1980s, which was less than 50 percent of GDP (Figure 1). Stock market capitalization as a percentage of GDP is also relatively high - even after making allowance for the boom in 2008 - compared with the Nordic countries in the early 1980s (Figure 8). Given its stage of development, China's financial system thus enjoys a relatively high level of intermediation and confidence. Taken together, these strong macroeconomic fundamentals, compared to the case of the Nordics, provide positive initial conditions for China's process of financial liberalization.

In addition, China's relative lack of financial openness, revealed in Figures 11 and 12, can - at least initially - help provide a controlled environment for reform by minimising the adverse impact of potentially volatile capital flows. The ratio of foreign assets to the total volume of assets of the banking system in Scandinavia is much higher than in China (Figure 11). Currently, Scandinavia is forging far ahead of China on this account. The same holds for the ratio of foreign liabilities to total liabilities (Figure 12). A similar picture emerges from inward foreign direct investments (Figure 13) and outward foreign direct investments (Figure 14), where Scandinavia is more open, in particular as regards outward flows.

Nevertheless, there remain major structural disadvantages relative to the Nordics. The Chinese economy is presently in transition from a centrally planned economy to a marketbased one. Although the process has been ongoing for 30 years, there is a large state-owned sector that is subject to soft budget constraints. This was not the case for the Nordics, as they are market economies. The banking system, the capital market and corporate governance are still at a relatively early stage of development in China, as highlighted in Table 1 . The legal 
system with regard to bankruptcy procedures, enforcement structure and the rights of creditors and debtors is far less developed than in the Nordic countries with their long legal tradition.

\subsection{Similarities between the Nordic countries and China}

Notwithstanding the above differences, there are important similarities that provide a sound basis for drawing lessons. First of all, China's financial system is dominated by four large state-owned commercial banks, and its financial reform and liberalization is part of the overall reform from centrally planned economy to market-based economy, which is also in line with China's WTO commitment. This is similar to the situation in the Nordic countries in the early 1980s, where banks dominated the financial system and financial reforms were part of a movement towards economic liberalization, catching up with the rest of Western Europe, as well as a way of moving towards closer European integration.

Secondly, China still has a large state-owned sector, which faces much less strict conditions when seeking loans from banks. Interest rates on deposits and loans are still controlled by the central bank, with a floor for lending rates and a ceiling for deposit rates. The lending-deposit rate gap is relatively large; commercial banks are under the protection of the central bank and interest income still dominates their revenue sources. Banking supervision is mostly administrative, although it has made some progress towards risk-based supervision. This is similar to the situation in the Nordic countries before liberalization, where interest rates were controlled, there was credit rationing with a large lending-deposit spread (Figure 9), real rates of interest were low (Figure 4), and stock and bond markets and foreign competition were kept at bay.

As a corollary to direct financial market intervention and administrative measures, policymakers and regulators in China today have little experience in managing financial liberalization. Monetary policy is largely based on quantitative regulations. This was also the case for the Nordics when they started on the road to financial liberalization in the 1980s.

Finally, on the external side, both China and the Nordics are open economies on the current account. China's current export share as a percentage of GDP is similar to that of the Nordic countries in the early 1980s, i.e. around 30 percent of GDP (Figure 10). From a historical perspective, the Nordics have benefitted from participating in the global economy, building 
their high standard of living on international trade and openness - a strategy that is similar to the case of China today. China's capital account is not fully liberalized, but the same was true for Finland, Norway and Sweden before liberalization.

\subsection{The case for learning lessons for China}

We suggest a number of reasons to support our case for drawing lessons for China from the Nordic experience of financial liberalization.

First of all, while the major differences between China and Scandinavia need to be borne in mind when lessons are being identified, the two economies share important characteristics as far as the state of the economy at the start of the process of financial deregulation is concerned: namely a bank-dominated financial system, strong credit controls, lack of risk management experience, lack of financial knowledge, and exchange controls, while at the same time being open on the current account. As a result, the incentives and processes unleashed by financial liberalization are likely to be similar.

Second, the Nordic reform experience is easily accessible and imparts lessons of a general nature. The failures and mistakes that occurred during the financial liberalization in the Nordic countries have been openly revealed by memoirs and comments published by politicians and bankers involved in the process, by government reports and by academic studies. The message from this literature may help Chinese policy-makers understand the dangers of financial liberalization and thus minimize the risks of managing financial deregulation.

Third, the history of boom-bust cycles across countries, across time and across various institutional frameworks suggests that financial crises possess some general characteristics. As long as there is a credit market, there will be a risk of boom-bust cycles. The issue for China is not to completely avoid boom-bust patterns -that is an impossible task - but to understand how boom-bust cycles interact with the financial liberalization process, how loose monetary policy may fuel credit booms, how to read the onset of a coming credit boom, so as to understand the policy actions that would minimize the cost of financial liberalization. A careful analysis of the record of financial deregulation and boom-bust cycles in the Nordic countries, as well as in other countries, can provide such lessons for China. 
Fourth, the successful record of Denmark demonstrates that financial opening does not need to end in a deep crisis, as long as the right macroeconomic and regulatory policies are in place. The Danish exception thus holds an important lesson for China as well.

Fifth, the Nordic countries maintained consensus around the policies adopted to handle the financial crisis, as well as consensus around an open financial system after the financial crisis. Thus, the crisis did not give rise to a political backlash against financial openness. Since Chinese policy-makers are concerned with keeping social tensions to a minimum, the Nordics' record may be of particular interest on this account.

Sixth, the financial reforms in the Nordics was part of a movement towards economic liberalization, catching up with the rest of Europe, as well as a way of moving them towards closer European economic integration. China is in a similar phase of transition towards a more open economy.

\section{Lessons for China from Scandinavia}

This section draws out six lessons from the Nordic experience of financial liberalization that we regard as being of interest for China. Of course, lesson-drawing is not an exact science. We do not claim to have made an unbiased selection - but merely to have focused on those features we believe are most relevant for China today. ${ }^{36}$

The first lesson concerns the dangers of financial ignorance. The second lesson suggests that reforms should be properly sequenced to minimize pro-cyclical effects. The third lesson covers the role of micro-prudential financial supervision during financial deregulation. From these insights, we derive our fourth lesson regarding the benefits of a flexible approach, embracing time for learning and preparedness to respond rapidly to emergencies. The fifth lesson stresses that financial liberalization may avoid crisis and costly losses to society - as long as it is designed properly. Finally, in our sixth lesson, we highlight the long-run benefits of financial liberalization.

\footnotetext{
${ }^{36}$ This section is based on the lessons of Nordic financial liberalization compiled by Jonung (2008). Here the focus is on the experience of Finland, Norway and Sweden.
} 


\subsection{Lesson 1: The dangers of financial ignorance}

The Nordic episodes illustrate the dangers of a lack of knowledge about the processes set in motion by financial liberalization and financial integration. If such knowledge is not to hand, then the proper response before, during and after financial liberalization is not likely to be forthcoming. When financial deregulation began in Scandinavia, decision-makers in all segments of society were trapped in a pattern of thinking that made little or no allowance for financially driven booms, busts and crises. This was the case of policy-makers in the central banks and the ministries of finance, as well as of forecasters of future economic developments, financial regulators, the economics profession, bankers and other actors in the financial system, and of the public at large.

The system of financial controls and regulations that had prevented the workings of financial markets since World War II created widespread financial ignorance or illiteracy. For this reason, when the process of financial liberalization started in the 1980s, the behaviour established during many decades of financial repression was continued without an understanding that the old risk-free world was rapidly being replaced by a new, and financially more risky world. Financial ignorance thus accounts for much of the behaviour that gave rise to the financial crisis.

Decision-makers in charge of monetary and fiscal policies commonly viewed steps towards financial deregulation in the mid-1980s as technical adjustments that were of no major consequence for aggregate economic performance. In addition, the first impact of financial liberalization was a lending boom with rising consumption and wealth, which was appreciated by the parties in political power. Thus, no major counteracting stabilization policy measures were taken until it was too late. Similarly, financial regulators were unaware of the risks created by financial deregulation and lax monetary and fiscal policies and took no effective action to slow the process of credit growth.

Official forecasts, made both within Scandinavia and by international organizations, failed to identify the boom-bust cycle. The errors in forecasts made at the end of the 1980s and at the beginning of the 1990s were much larger than the average errors for the post-war period. Forecast errors emerged during both the boom and the bust phases of the cycle. At the end of the 1980s, when the economy was overheated, it took longer than expected for it to cool down. 
When the bust and downturn came, it was much deeper than expected, and once again the recovery from the crisis was faster than most commentators had anticipated. The systematic collective bias in forecast performance, reflecting the lack of knowledge by professional forecasters about financial events, contributed to serious policy mistakes.

Economists at universities in Scandinavia were caught up in a Keynesian world of flow variables, being unfamiliar with the wealth, portfolio and balance sheet effects created by financial liberalization and changes in real interest rates. As a rule, economists were in favour of financial liberalization. They viewed deregulation as part of a supply-side approach aimed at improving growth performance, with little understanding of the imbalances and dangers that financial deregulation could bring about if it were not combined with proper countermeasures such as more restrictive monetary and fiscal policies. Thus, few warnings emerged from the economics profession at a time when such advice would have been most appropriate.

Bankers and other actors on financial markets were ignorant of the change in the rules of the game. They lacked an understanding of the workings of unregulated financial markets because they had only experienced a financially closed and strongly regulated economy, where financial risks were exceptionally limited. The same held for private individuals and firms. As soon as credit became freely available, borrowers rapidly turned to the financial sector to enter deep into debt. Thus, the credit boom was fuelled by lenders and borrowers with little understanding of the risks of unsustainable loan expansion.

The policy lesson for China is simple. A thorough analytical and factual understanding of the consequences of a move towards financial integration, and of the workings of unfettered financial markets, is crucial to making financial liberalization and subsequent financial integration successful. Financial knowledge should be as widely disseminated as possible: among domestic policy-makers, regulators, official and private forecasters, economists, financial sector participants and, most importantly, among the public at large. When China deregulates its financial markets in the future, new financial risks are likely to build up through the emergence of new instruments and techniques that did not exist in the Nordics in the 1980s. Of course, these cannot be predicted today, but financial literacy, including proper learning from other countries, can help in the design of a balanced response to financial integration. The history of financial crisis suggests that particular attention should be paid to the growth of credit aggregates, as credit is the main driver of boom-bust cycles. Moreover, 
relatively stable interest rate margins, as in the case of the Nordics, may have masked the growing risks that banks were actually taking in the competition for market shares, when they ventured into new markets and product segments where they had scant experience of risk management.

\subsection{Lesson 2: The importance of sequencing reforms to avoid pro-cyclicality}

The Nordic record of financial liberalization demonstrates that the sequencing of financial reforms, internally and externally, on the route to financial liberalization is of the utmost importance in determining macroeconomic performance. It is the key to the ruinous record of Finland and Sweden. To summarize, financial markets were first deregulated internally in the mid-1980s, which set off a sharp lending boom, fuelled by an inflow of capital, while outflows were prevented by capital controls. Later, at the end of the 1980s, financial markets were externally deregulated, allowing an outflow of capital, while the central banks chose to defend the pegged exchange rate with high interest rates. The pegged exchange rate was then abandoned when the crisis reached its peak. An earlier floating or adjustment of the peg could have dampened the boom-bust pattern - or even eliminated it if financial liberalization had simultaneously been combined with a floating rate.

First of all, as discussed in Box 1, financial liberalization under given tax incentives meant that, for the three crisis-ridden Nordic countries, real after-tax interest rates were initially kept at a very low level through favourable taxation of interest payments on loans. However, taxation was changed in various stages in all three countries, which raised real after-tax interest rates significantly. Tax rules thus made a procyclical contribution, fuelling the boom and exacerbating the bust. In a more appropriate sequencing, taxation would have been reformed at a very early stage of the financial liberalization process.

Second, by maintaining and defending the pegged rate of their currencies, the Nordic countries created a strongly procyclical monetary policy both during and after financial liberalization. During the boom phase, interest rates could not be raised to counter the boom, because that would have increased capital inflows and thus strengthened the credit boom. Once the cycle started to turn downwards, the pegged exchange rate had to be defended by raising the domestic interest rates, thus contributing to the downturn. Eventually, the defense of the peg made the domestic crisis so deep that the peg had to be abandoned. This happened 
in the autumn of 1992: in September in Finland, in November in Sweden and in December in Norway.

Thirdly, fiscal policy, i.e. the design of taxes and government expenditures, played a key role in the process of financial liberalization. During the boom phase, it was commonly procyclical. Although the fiscal authorities apparently believed that fiscal policy was contractionary because budget surpluses were being registered, these surpluses were too small to counterbalance the boom. Fiscal policy should therefore have been much tighter. During the bust phase, primarily due to the workings of automatic stabilizers, budget deficits expanded extremely rapidly. Now, the rise in deficits prompted far-reaching policy measures to reduce government expenditures and raise taxes in Finland and Sweden, thereby making the recession deeper.

The policy lesson for China is that policy-makers should consider the macroeconomic or cyclical consequences of structural changes in regulation and taxes, of the exchange rate regime and of the fiscal regime. Tax reforms may be highly recommendable as part of a policy for improved growth and efficiency, but they may also have undesirable effects when interacting with other developments. Thus, policy-makers should pay careful attention to initial conditions when changing prevailing financial regulations and schemes of taxation. The same holds for the potential pro-cyclicality of the workings of the exchange rate regime. Most prominently, the existence of a pegged but adjustable exchange rate can easily amplify cyclical developments during a process of financial liberalization, thus creating a conflict between internal and external stability. This lesson is illustrated not only by the Nordics, but also by the experience of the crisis in many other countries. ${ }^{37}$

Concerning China, it may be prudent to focus reforms initially on the domestic front so as to strengthen the financial system before it is exposed to international competitive forces. Moving beyond this initial phase, the currency crises in Scandinavia show that risks arising from external opening can be mitigated by allowing greater exchange rate flexibility before, or at least in conjunction with, capital account opening. Not only can monetary policy effectiveness be maintained to a greater extent, but also banks have stronger incentives to

\footnotetext{
${ }^{37}$ Wyplosz (2001, p. 157), summarizing the post-World War II European experience of financial repression and liberalization, states "The lifting of capital controls requires the end of any fixed exchange rate regime that might have been in place."
} 
control the currency risks arising from cross-border financial flows. As a result, the procyclical forces inherent in providing financial institutions with a greater degree of freedom can be tamed. Moreover, in terms of timing, the Nordic experience shows that the capital account should be opened when inflow or outflow pressures arising from the position in the economic cycle are minimal.

\subsection{Lesson 3: The limits of micro-prudential financial supervision}

Prior to the financial deregulation in the mid 1980s, the system of financial supervision was well developed in Finland, Norway and Sweden, albeit with a focus on correct accounting. There were no weak banks, no "crony banking", no dubious links between banks and industrial companies, political parties or private families reflecting nepotism and corruption. In addition, no banks were dependent on state subsidies or state support. Still, in spite of the existing financial supervision, the financial crises of the early 1990s brought the entire banking system close to collapse, prompting major government financial intervention, forcing several banks into bankruptcy or into obtaining support through public funds.

The policy lesson for China is that conventional micro-prudential financial supervision, adopted to monitor tightly regulated financial institutions, is not up to the task of preventing a deep crisis from developing within the financial system. The forces of boom and bust unleashed among the Nordics were simply too strong to be neutralized by such financial supervision. ${ }^{38}$ Thus, it is imperative to reform the supervisory system prior to or simultaneously with financial liberalization. Still, no financial supervision, however adequate and efficient, can prevent the emergence of a systemic financial crisis of the type that hit the Nordic countries in the early 1990s if the proper macroeconomic policies are not in place.

\subsection{Lesson 4: The benefits of a flexible and cautious approach}

The Nordic countries - with the exception of Denmark - applied a "big bang" approach to financial liberalization, thus creating a strong boom-bust cycle by "opening the floodgates". Also, the Nordic economies were all market-based systems when they were financially

\footnotetext{
${ }^{38}$ The same lesson holds for deposit insurance. Finland and Norway had such a system. Sweden acquired one as a result of the crisis. The crisis proved that deposit insurance was an insufficient arrangement. Instead, the government served as the ultimate guarantor of the stability of the banking system.
} 
liberated. China starts from a different position, that of an economy in transition, which makes the process more complicated and therefore riskier.

The lesson is that China should avoid a 'big bang' approach to financial liberalization as applied by the Nordics, and should instead adopt a cautious approach by liberalizing in small steps. This strategy will allow time to learn from mistakes and provide the opportunity to back-track if signs of major tensions develop, thereby minimizing the risk of financial turmoil. Also, the Nordics had no early warning system when they started on the road towards financial liberalization. The lesson for China is to put such a system in place prior to full liberalization. ${ }^{39}$

In addition to monitoring emerging risks, a cautious and flexible approach also includes the option to respond quickly and decisively if a financial crisis develops. In the case of the Nordics, the process of financial liberalization set off a chain of events that threatened to wipe out the entire equity of many banks. At that stage, far-reaching steps were taken in Finland to support the banking system; the savings bank group was taken over by the government. In Norway, the three biggest banks were nationalized, eliminating private ownership completely. The government of Sweden offered a blanket assurance for claims on Swedish commercial banks, nationalized the two insolvent banks, and set up asset management corporations to take over the bad assets of the remaining commercial banks. ${ }^{40}$

The Swedish approach is commonly praised for being swift and resolute. ${ }^{41}$ It prevented bank runs; it maintained the solvent commercial banks in private ownership and allowed banks to continue financial intermediation, averting any credit crunch; it kept moral hazard for shareholders at bay, and it was transparent. Eventually, the bad assets taken over by the asset management corporations turned out to be something of a financial success once the economy had recovered; at least the losses turned out to be much smaller than initially expected.

The policy lesson for China is clear in a case where deregulation contributes to a crisis. Rapid, transparent and determined government action to maintain public confidence in the strength

\footnotetext{
${ }^{39}$ For example, the volume of credit and bank loans should be monitored closely. Any growth exceeding nominal GDP-growth should be considered as a warning signal. Asset price movements should also be followed closely. The actions of banks as well as non-bank financial intermediaries should be covered.

${ }^{40}$ See the account by Englund and Vihriälä (2009).

${ }^{41}$ The Swedish approach to resolution, covered in several studies, is summarized in Jonung (2009).
} 
of the banking system reduces the impact of a financial crisis, dampens any credit crunch and allows for a rapid recovery of the financial system and thus of the real economy.

There is an additional reason for China to be cautious. The Nordic countries are small economies with stable political traditions. They can experiment and have failures, without this leading to international consequences. China, in contrast, is an economic giant. If China makes serious policy mistakes when liberalizing its financial system, this may have a strong negative effect upon the rest of the world, in particular on other East Asian countries, not to mention far-reaching economic and political effects within China.

While the pace of reform should be gradual, it should also be steady. The Nordic countries did not halt or reverse their liberalization process in response to the crisis. The lesson in this for China is that gradualism should be tempered by the importance of avoiding a stop-go policy. Once the momentum for a more competitive and open financial system is created, halting or doing a U-turn could entail higher costs than continuing onwards with appropriate modifications that reflect actual learning.

\subsection{Lesson 5: Financial liberalization can lead to costly crises, but it does not have to}

The loss in output and industrial production in the early 1990s is large compared to the outcome of previous major crises among the Nordics, as Table 2 shows. There is no event of a similar magnitude in the entire post-World War II period. It matches the depression of the 1930 s, commonly regarded as the most severe crisis of the $20^{\text {th }}$ century. Indeed, the financial crisis of the early 1990s is unique. It represents a sharp break with the business cycle pattern post-World War II, particularly in Finland and Sweden.

From the fact that Finland, Norway and Sweden ended up in a deep crisis after financial liberalization, it is tempting to conclude that financial liberalization is bound to lead to crisis and can only be attained at a high cost to society. The Nordic experience demonstrates that such a conclusion is incorrect. The record of Denmark shows that financial liberalization can be implemented without creating a sharp boom-bust pattern. ${ }^{42}$

\footnotetext{
${ }^{42}$ Denmark is not the only country in Europe that designed its financial liberalization without creating a financial crisis. Austria and the Netherlands can be taken as further examples.
} 
The policy lesson for China is that it is possible to carry out financial liberalization without causing a dramatic crisis across the whole economy. This requires, as stressed in the previous lessons above, that a general understanding of the processes unleashed by financial deregulation exists, that the authorities maintain a proper timing of the process of deregulation, that financial supervision is working, and that financial liberalization is conducted in a flexible and cautious manner.

\subsection{Lesson 6: Financial liberalization has long-run benefits}

The Nordic experience demonstrates that financial liberalization and the process of intensified financial integration that started once the barriers for cross-border financial flows were eliminated do have long-run beneficial effects on the conduct of stabilization policies and on the growth potential of the economy.

For China, the long-run effects of financial liberalization are also most likely to be highly beneficial on its way to becoming the biggest economy in the world. A properly functioning financial system is a key determinant of growth and transformation. This would give China a greater degree of freedom in determining the strategy for its monetary policy too. With a market-oriented financial system, monetary policy can be focused to a larger extent than at present on domestic conditions. In future, the Chinese currency will be among the major reserve currencies. For this to happen, China must have a financial system that is open to the world.

There are risks of postponing adjustment to an open financial system too. The costs of financial underdevelopment in the form of misallocation of credit, inferior stabilization policies and the build-up of financial imbalances, should also figure high on the agenda. The status quo is a costly state. This strengthens the case for speeding up the financial opening of China.

The lesson here is simple. By opening up to international trade in recent decades, China has been surfing the global economy with success so far - but not to the full extent. The Nordic economies followed a similar strategy both before and after international financial integration. This suggests that financial opening is not a threat to the growth performance of China. 


\section{Conclusions}

This report has identified a set of policy lessons from the experience of the process of financial liberalization, of the ensuing financial crisis and recovery in Scandinavia during the period 1985-2000 that are deemed relevant for China today. These are as follows: (1) financial liberalization can be implemented without creating a deep financial crisis, (2) a thorough understanding by policy-makers and financial market participants of the behavioural and institutional linkages within the financial system and to the rest of the economy and the workings of open financial markets is central to making financial liberalization successful, (3) policy-makers should pay careful attention to initial conditions concerning regulation, taxes and exchange rate arrangements when moving towards financial openness, (4) the financial supervisory system should be reformed prior to or simultaneously with financial liberalization, (5) a "big bang" approach to financial liberalization as applied by the Nordics should be avoided, preferring instead a cautious approach by liberalizing in small, but substantive steps, and (6) the long-run effects of financial liberalization are most likely to be highly beneficial for China. A properly functioning financial system is a key determinant of growth and transformation. Maintaining the present status quo of financial underdevelopment brings high costs and the risk of abrupt - and thus very damaging - changes in the future.

These policy lessons should be viewed as a package, because they are closely related. It is not sufficient to select a few and ignore the others. The approach to financial reform should be system-wide; otherwise there is a great risk that it will create problems along the road to financial openness.

Financial reform and liberalization strike us as urgent issues, as China's transition to a market-based economy is far from completed. Yet, given the complexity of the challenges ahead, arising from the intricate interdependencies with progress in other areas of reform and the need for maintaining stability, future financial reforms need to strike a careful balance between being gradual and substantive.

Nevertheless, financial liberalization is still a risky venture. The short-run costs and risks must be compared with the long-run benefits. The costs or risks can be minimized if China is ready to learn the lessons from countries that have undergone financial liberalization - and the Nordics provide valuable lessons for China on this account. 
Last, amid the present global financial crisis, there is growing doubt about the benefits of financial opening and financial liberalization. The Nordic experience does provide us with one clear-cut conclusion on this issue. None of the three Nordic countries that suffered the huge costs of financial crisis has taken steps to return to financial autarchy, to close its borders for capital flows, or otherwise to turn the clock back. This suggests that the benefits of financial integration outweigh its costs, even when those costs turn out to be very high for society in the short run. 


\section{References}

Aizenman, J., and J. Lee, (2008), "Financial versus monetary mercantilism: Long-run view of large international reserves Hoarding", The World Economy, pp. 593-611.

Allen, F., J. Qian, and M. Qian, (2005), “China's financial system: Past, present and future,” mimeo, University of Pennsylvania, Philadelphia.

Allen, M., C. Rosenberg, C. Keller, B. Setser and N. Roubini, (2002), "A balance sheet approach to financial crisis", IMF working paper, WP/02/210, Washington DC.

Andersen, T., B. Holmström, S. Honkapohja, S. Korkman, H, Söderström, J. Vartiainen, (2007), The Nordic model. Embracing globalization and sharing risks, ETLA, Helsinki.

Aziz, J., (2006), "Rebalancing China's economy: What does growth theory tell us?", IMF working paper 06/291, Washington DC.

Aziz, J., and L. Cui, (2007), "Explaining China's low consumption: The neglected role of household income", IMF working paper 07/181, Washington DC.

Barnett, S., (2004), "Banking sector developments", in: China's growth and integration into the world economy, Prasad, E. (ed.), IMF occasional paper 232, Washington DC.

Blanchard, O., F. Giavazzi and F. Sa, (2005), "International investors, the U.S. current account, and the dollar", Brookings Papers on Economic Activity, vol. 1, pp. 1-49.

Bordo, M., B. Eichengreen, D. Klingebiel and M. Soledad Martinez-Peria, (2001), "Is the crisis problem growing more severe?", Economic Policy, pp. 51-82.

Bussière, M., and A. Mehl, (2008), "China's and India's roles in global trade and finance. Twin titans for the new millennium?", European Central Bank, occasional paper series 80, Frankfurt.

Caballero, R., E. Farhi, and P. O. Gourinchas (2008), "An equilibrium model of global imbalances and low interest rates”, American Economic Review, vol. 98, pp. 358-93.

Callesen, P., S. Lohmann Poulsen and R. Degn, (2008), "Har fastkurspolitikens option en positiv eller en negative vaerdi?", discussion paper for a conference of Nationaløkonomisk Forening, January, Department of Finance, Copenhagen.

Calmfors, L., (2007), "Scandinavia today: An economic miracle?", chapter 4 in The EEAG Report on the European Economy 2007, CESifo Group, Munich.

Cappiello, L., and F. Gianluigi, (2008), "The sustainability of China's exchange rate policy and capital account liberalisation", European Central Bank, occasional paper series 82, Frankfurt.

Caprio, G., D. Klingebiel, L. Laeven and G. Noguera, (2005), "Banking crisis database", appendix to P. Honohan and L. Laeven, eds., Systemic financial crises. Containment and resolution, Cambridge University Press, Cambridge. 
Cooper, R., (2008), "Global imbalances: Globalization, demography and sustainability", Journal of Economic Perspectives, vol. 22 (3), pp. 93-112.

Dollar, D. and S. Wei (2007), "Das (Wasted) Kapital: Firm ownership and investment efficiency in China", IMF working paper 07/9, Washington DC.

Dunaway, S., L., Leigh, and X. Li (2006), "How robust are estimates of equilibrium real exhange rates: The case of China”, IMF working paper 06/220, Washington DC.

Drees, B. and C. Pazarbasioglu, (1998), "The Nordic banking crisis. Pitfalls in financial liberalization", Occasional Paper 161, IMF, Washington DC.

EFTA (1994). European economic integration. Effects of "1992" on the services sectors of the EFTA countries, Occasional Paper 49, December, Geneva.

Englund, P. and V. Vihriälä, (2009), "Financial crisis in Finland and Sweden: Similar but not quite the same", chapter 3 in L. Jonung, J. Kiander and P. Vartia, eds., The great financial crisis of the 1990s in Finland and Sweden. The Nordic experience of financial liberalization, Edward Elgar.

Ems, E., (1994a), "EEA and the financial services sectors in Sweden", Occasional Paper 9, Sveriges Riksbank, Stockholm.

Ems, E., ed., (1994b), "Financial integration in Western Europe. Structural and regulatory consequences", Occasional Paper 10, Sveriges Riksbank, Stockholm.

Farrell, D., S., Lund, J. Rosenfeld, F. Morin, N. Gupta and E. Greenberg, (2006), "Putting China's capital to work: The value of financial system", McKinsey Global Institute, McKinsey Company.

Forbes, K., (2008), "Why do foreigners invest in the United States?", Federal Reserve Bank of San Francisco, working paper series 2008-27.

Goodfriend, M. and E. Prasad, (2006), "A framework for independent monetary policy in China", IMF working paper 06/111, Washington DC.

Guonan, M., and R. McCauley, (2007), "Do China's capital controls still bind? Implications for monetary autonomy and capital liberalisation", Bank for International Settlements, BIS working paper 233, Basel.

Haltmaier, J., S. Ahmed, B. Coulibaly, R. Knippenberg, S. Leduc, M. Marazzi, and B. A. Wilson, (2007), "The role of China in Asia: Engine, conduit, or steamroller?", International Finance Discussion Papers 904, Board of Governors of the Federal Reserve System, Washington DC.

Henrekson, M. and U. Jakobsson, (2005), "The Swedish model of corporate ownership and control in transition", chapter 7 in H. Huizinga and L. Jonung, eds., The internationalisation of asset ownership in Europe, Cambridge University Press, Cambridge. 
Henry, P. B., (2007), "Capital account liberalization: Theory, evidence, and speculation", Journal of Economic Literature, pp. 887-935.

Hope, N., and F. Hu, (2007), "Reforming China's banking system: How much can foreign strategic investment help?" in J. Aziz, S. Dunaway and E. Prasad, eds., China and India: Learning from each other: Reforms and policies for sustained growth, International Monetary Fund, Washington DC.

IMF (1998), World Economic Outlook, May, IMF, Washington DC.

James, H., (2001), The end of globalization. Lessons from the Great Depression, Harvard University Press, Cambridge and London.

Jonung, L., (2008), "Lessons from financial liberalisation in Scandinavia", Comparative Economic Studies, vol. 50, pp. 564-598.

Jonung, L., (2009), "'The Swedish model for resolving the banking crisis of 1991-93. Seven reasons why it was successful. European Economy, Economic papers 360, European Commission, February 2009, Brussels.

http://ec.europa.eu/economy finance/publications/publication summary14130 en.htm

Jonung, L., J. Kiander and P. Vartia, (2009), "The great financial crisis in Finland and Sweden: The dynamics of boom, bust and recovery 1985-2000", chapter 5 in L. Jonung, J. Kiander and P. Vartia, eds., The great financial crisis of the 1990s in Finland and Sweden. The Nordic experience of financial liberalization, Edward Elgar. (A longer version published in European Economy, Economic papers 367, December, 2008. European Commission. Brussels.

http://ec.europa.eu/economy finance/publications/publication summary13549 en.htm

Ju, J. and S. J. Wei, (2007), "Domestic institutions and the bypass effect of financial globalization", NBER working paper 13148, Cambridge.

Kose, M.A., E. Prasad, K. Rogoff and S. J., Wei, (2006), "Financial globalisation: A reappraisal", CEPR discussion paper 5842.

Li, X. and S. Dunaway, (2005), "Estimating China's "equilibrium" real exchange rate, IMF working paper 05/202, Washington DC.

Lueth, E. and M. Syed (2006), "Rising inequality and polarization in Asia", Asia Pacific Regional Economic Outlook, World Economic and Financial Survey, International Monetary Fund, Washington, DC.

McKinnon, R. and G. Schnabl, (2008), "China's exchange rate impasse and the weak U.S. dollar", CESiFO working paper 2386.

Ng, B. K., (2007), "Banking reform in China: An assessment in macroeconomic perspective", Economic Growth Centre, Singapore, working paper 2007/07.

Podpiera, R., (2006), "Progress in China's Banking Sector Reform: Has Bank Behaviour Changed?" IMF working paper 06/71, Washington DC. 
Prasad, E., T. Rumbaugh and Q. Wang, (2005), "Putting the Cart Before the Horse? Capital Account Liberalization and Exchange Rate Flexibility in China", IMF Policy Discussion Paper 05/1, Washington DC.

Roine, J., J. Vlachos and D. Waldenström, (2008), “The long-run determinants of inequality: What can we learn from top income data?", IFN working paper 721, Stockholm.

Schaumann, A., (1993), "Dansk økonomisk politik 1982-1992" (Danish economic policy 1982-1992), report 20 in part 2 of Nya villkor för ekonomi och politik. Ekonomikommissionens förslag. SOU 1993:16, finansdepartementet, Stockholm.

Schwierz, C., (2004), "Economic costs associated with the Nordic banking crises", chapter 4 in Moe, T., J. Solheim and B. Vale., eds., The Norwegian banking crisis, Occasional Papers 33, Bank of Norway, Oslo.

Sherif, K., M. Borish and A. Gross (2003), "State-owned banks in the transition: Origins, evolutions and policy responses", mimeo, World Bank, Washington DC.

Steigum, E., (2009), "The boom and bust cycle in Norway", chapter 7 in L. Jonung, J. Kiander and P. Vartia, eds., The great financial crisis of the 1990s in Finland and Sweden. The Nordic experience of financial liberalization, Edward Elgar.

Tang, H., E. Zoli and I. Klytchnikova, (2000), "Banking crises in transition economies Fiscal costs and related issues", World Bank Policy Research Working Paper 284, Washington DC.

Tornell, A. and F. Westermann, (2005), Boom-bust cycles and financial liberalization, MIT Press, Cambridge and London.

Unteroberdoerster, O., (2004), "Banking reform in the lower Mekong countries", IMF policy discussion paper 04/05, Washington DC.

Vastrup, C., (2009), "How did Denmark avoid a banking crisis?", chapter 8 in L. Jonung, J. Kiander and P. Vartia, eds., The Crisis of the 1990s in Finland and Sweden. The Nordic experience of financial liberalization, Edward Elgar.

Wyplosz, C., (2001), "Financial restraints and liberalization in postwar Europe", chapter 5 in G. Caprio, P. Honohan and J. Stiglitz, eds., Financial liberalization. How far, how fast?, Cambridge University Press, Cambridge.

Ylä-Antilla, P., J. Ali-Yrkkö and M. Nyberg, (2005), "Foreign ownership in Finland boosting firm performance and changing corporate governance", chapter 8 in H. Huizinga and L. Jonung, eds., The internationalisation of asset ownership in Europe, Cambridge University Press, Cambridge. 


\section{Box 1. The procyclical effect of after-tax real rates}

The boom-bust episode 1985-93 in Finland, Norway and Sweden demonstrates the central role that rapid, large and unexpected changes in the real rate of interest, or more correctly in the after-tax real rate, may play in driving macroeconomic developments during the opening of financially closed economies with pegged but adjustable exchange rates.

Prior to financial liberalization, the real rate in all three countries was negative, often in the range of minus 2-4 percent as a consequence of prevailing internal and external financial controls, the system of tax deductible interest payments on mortgage loans and high inflation and well entrenched inflation expectations. The negative real rates created extremely strong incentives for individuals and firms to accept more debt when controls were abolished and credit became freely available in the mid 1980s, thus driving the loan expansion. Banks and other financial intermediaries responded by increasing the supply of loans.

Eventually, after major changes in the tax system, falling inflation and rising nominal interest rates, real after-tax rates turned positive, breaking the boom phase and reaching a peak during the end of the bust. At this stage, the real rate had reached uniquely high levels. The sharp - and to a large extent unexpected - rise in the real rate of interest created huge negative balance sheet or wealth effects, sharply reducing investments and consumption and raising private sector savings as the private sector tried to rebalance the composition of their portfolios. These contractionary balance sheet effects undermined the entire financial system, the wealth position of the private sector and the budget of the public sector.

Other factors were at work too, influencing the boom-bust pattern. However, these factors were of secondary importance compared to the role of financial market developments. Without financial deregulation, the business cycle in Finland, Norway and Sweden during the period 1985-93 would have stayed less volatile and moved closer to the traditional cyclical pattern. 
Table 1. Initial conditions for financial liberalization: Scandinavia and China. A stylized view.

Scandinavia China

(about 1985) (about 2008)

A. Key characteristics of financial system

- Banking system

Non-bank system

- Supervision

- Competition
Dominated by a few large commercial banks, and many small savings banks. The roots of the banking system stem from the $19^{\text {th }}$ century.

Stock market, bond market and insurance sector kept at bay by financial regulations, no major nonbank financial intermediaries. (except finance companies) Foreign bank activities severely restricted or prohibited

Supervision based on formal control of bank lending and adherence to other regulation, without explicit risk supervision
Dominated by four state-owned banks (SOCBs) established with break-up of monobank system in 1984; commercial bank law since 1995; establishment of first non-state commercial bank in 1996

Emerging stock market, created in 1990 with very limited free float and dominated by state-owned enterprises; nascent bond market, hampered by regulatory, legal and structural weaknesses.

Significant progress in establishing framework for prudential supervision, including establishment of bank and securities regulators, CBRC (2003) and CSRC (1990); gradual phase-in of bank solvency framework towards BIS standards, as well as international best practice in accounting and classification standards.

No competition legislation and institutions; competition from foreign banks gradually phased-in under WTO commitments; competition from smaller joint-stock banks hampered by thin/inefficient interbank market (in part reflecting the PBC's frequent use of reserve requirements).
B. Incentives for risk management

- Legal system

$$
\begin{aligned}
& \text { Strong legal system concerning } \\
& \text { bankruptcy procedures. ("rule of } \\
& \text { law") }
\end{aligned}
$$

- Governance

- Capital
Strong central bank control of the flow of credit. Mostly private ownership of commercial and savings banks.

Capital raised through the private sectors.
Weak enforcement of bankruptcy law (first adopted in 1998) and other creditor rights implies preference for borrowers with implicit or explicit state guarantees, such as state-owned enterprises (SOEs).

Role of state as owner, supervisor, and customer of banks can create significant conflicts of interest, marring management accountability, performance-based salaries and promotions, and commercial decisionmaking; foreign strategic investors beginning to play a role in governance and risk management.

Repeated state-funded recapitalization of SOCBs (1998, 1999, 2000, 2003, 2004, $2005)$ to compensate for legacy NPLs. 


\begin{tabular}{ll}
\hline $\begin{array}{l}\text { Scandinavia } \\
\text { (about 1985) }\end{array}$ & $\begin{array}{l}\text { China } \\
\text { (about 2008) }\end{array}$ \\
\hline
\end{tabular}

- Financial system controls

- Interest rate Interest rate controls, explicit or controls implicit, by the central bank.

- Rationing of Rationing of credits through the credit central bank and other public authorities.

- Exchangerate regime

Pegged exchange rates to currency baskets.

- Capital account controls

Capital controls in effect since World War II after some liberalization in the 1970s.
Some liberalization of interest rates, but floor on lending and cap on deposit rates.

Directed lending gradually phased-out around 1998, but continued significant lending from SCBs to SOEs; lending quotas ("window guidance") remain key monetary policy tool (see below); together with targets for NPL reduction this can provide incentive to rollover hidden NPLs to SOEs.

Pegged to US dollar until July 21, 2005; currently classified as crawling peg.

Gradual relaxation with most transactions still subject to controls thereby shielding domestic banking system from international competition; total qualified foreign institutional investors (QFII) quota is US\$30 billion (less than 1 percent of stock market capitalization); total qualified domestic institutional investor (QDII) quota is US $\$ 48.5$ billion

C. Macroeconomic environment

- Monetary policy framework

- Key Full employment stabilization objectives remains the main policy goal after the breakdown of the Brettons Woods system in the early 1970 s.

- Status of The central bank under the central bank (unofficial) control of the government via the ministry of finance.

- Key policy Quantitative regulations of the flow instruments of credit and the setting of interest rates, including steering credits to prioritized objectives such as financing of government budget and subsidizing housing. A gradual acceptance of more market-oriented techniques, financial deregulation in small steps starting in the 1970s.

Devaluations of the exchange rate in the second half of the 1970s and early 1980s.
Defined as maintaining the stability of the value of the currency in order to promote economic growth.

The People's Bank of China (PBC) must report to the State Council its decisions concerning the annual money supply, interest rates, exchange rates and other important issues specified by the State Council for approval. The PBC is also obliged to submit reports to the Standing Committee of the National People's Congress on the conduct of monetary policy and the performance of the financial industry.

Emphasis is on use of reserve requirement ratio and central bank base interest rate, as well as quantitative lending quotas, but other instruments include, rediscounting, central bank lending, and increasingly open market operation. 


\begin{tabular}{|c|c|c|}
\hline & $\begin{array}{l}\text { Scandinavia } \\
\text { (about 1985) }\end{array}$ & $\begin{array}{l}\text { China } \\
\text { (about 2008) }\end{array}$ \\
\hline $\begin{array}{l}\text { - Recent performance } \\
\text { - Inflation } \\
\text { track record }\end{array}$ & $\begin{array}{l}\text { and vulnerabilities } \\
\text { High inflation in the late } 1970 \text { s and } \\
\text { early 1980s as part of an } \\
\text { accommodative policy of devaluation } \\
\text { to maintain full employment. }\end{array}$ & $\begin{array}{l}\text { Periods of double-digit inflation in part } \\
\text { reflecting price liberalization; state } \\
\text { procurement and non-market prices are } \\
\text { now largely phased out, with average } \\
\text { annual CPI inflation over past five years } \\
\text { about } 2 \frac{1}{2} \text { percent. }\end{array}$ \\
\hline $\begin{array}{ll}\text { - } & \text { Fiscal } \\
& \text { position }\end{array}$ & $\begin{array}{l}\text { Large budget deficits accepted after } \\
\text { OPEC I and II to maintain high } \\
\text { domestic aggregate demand (to fight } \\
\text { unemployment) in the late } 1970 \text { s and } \\
\text { early 1980s. }\end{array}$ & $\begin{array}{l}\text { Strong real GDP growth has resulted in } \\
\text { better-than-budgeted revenue per- } \\
\text { formance and smaller deficits in recent } \\
\text { years, with a low official government } \\
\text { debt level of } 21 \text { percent of GDP; } \\
\text { contingent liabilities from a weak } \\
\text { banking system and demographic } \\
\text { changes may be large; sovereign credit } \\
\text { rating is A- (S\&P), A2 (Moody's) and } \\
\text { A- (Fitch). }\end{array}$ \\
\hline $\begin{array}{l}\text { External } \\
\text { position }\end{array}$ & $\begin{array}{l}\text { Improved current account position } \\
\text { after OPEC I and II and repeated } \\
\text { devaluations. }\end{array}$ & $\begin{array}{l}\text { Strong; current account surplus has } \\
\text { averaged } 7 \text { percent of GDP over last five } \\
\text { years, gross official reserves exceeded } \\
\text { US } \$ 1.5 \text { trillion ( } 14 \text { months of imports) at } \\
\text { end } 2007 \text {. }\end{array}$ \\
\hline
\end{tabular}

Source: Authors' assessment, EFTA (1994), Ems (1994a, 1994b), Goodfriend and Prasad (2006), Hope and $\mathrm{Hu}$ (2007), People's Bank of China and IMF country reports.

Comments: Table 1 covers Finland, Norway and Sweden in the mid 1980s. Denmark is excluded, as it was financially more open than its Nordic neighbours in the 1980s. 
Table 2. The costs of major crises in Scandinavia 1877-2000 in terms of foregone growth in real income and in industrial production relative to trend (percentage points).

\begin{tabular}{lccccccc}
\hline Crisis of: & $\mathbf{1 8 7 7 - 7 8}$ & $\mathbf{1 8 8 6}$ & $\mathbf{1 9 0 0}$ & $\mathbf{1 9 0 7}$ & $\mathbf{1 9 2 0 s}$ & $\mathbf{1 9 3 0 s}$ & $\mathbf{1 9 9 0 s}$ \\
\hline 1. Loss of real income & & & & & & & \\
Denmark & 5,1 & No crisis & No crisis & No loss & No loss & 6,5 & No crisis \\
Period below trend & 1877 & - & - & - & - & 1932 & - \\
Finland & 24,2 & No crisis & 10,4 & No crisis & No crisis & 24,3 & 26,4 \\
Period below trend & $1877-81$ & - & $1900-01$ & - & - & $1929-32$ & $1990-93$ \\
Norway & No crisis & 0,7 & 1,4 & No crisis & $21,5^{*}$ & 13,3 & 12,4 \\
Period below trend & - & $1885-86$ & 1900 & - & 1921 & 1931 & $1988-93$ \\
Sweden & 11,3 & No crisis & No crisis & 11,2 & $9,6^{*}$ & 17,7 & 13,0 \\
Period below trend & $1877-78$ & - & - & $1908-09$ & 1921 & $1931-33$ & $1990-93$ \\
2. Loss of industrial production & & & & & & & \\
Denmark & 10,6 & No crisis & No crisis & No loss & No crisis & 18,4 & No crisis \\
Period below trend & $1877-78$ & - & - & - & - & $1931-32$ & - \\
Finland & 72,2 & No crisis & 21,0 & No crisis & No crisis & 46,4 & 21,4 \\
Period below trend & $1876-79$ & - & $1901-02$ & - & - & $1930-33$ & $1990-92$ \\
Norway & No crisis & no data & no data & No crisis & $36,9^{*}$ & $26,3 * *$ & 2,7 \\
Period below trend & - & - & - & - & 1921 & 1931 & 1988 \\
Sweden & 14,7 & No crisis & No crisis & 17,3 & $19,8^{*}$ & 30,9 & 17,0 \\
Period below trend & $1877-78$ & - & - & $1908-09$ & 1921 & $1930-33$ & $1990-93$ \\
\hline & & & & & & &
\end{tabular}

Comments: * two-year trend used, ** four-year trend used.

Source: Jonung (2008). 
Table 3. Key demographic and economic characteristics of China and the Nordics in 2007

\begin{tabular}{|c|c|c|c|c|c|c|}
\hline & China & Denmark & Finland & Norway & Sweden & $\begin{array}{r}\text { The } \\
\text { Nordics }\end{array}$ \\
\hline Population (in million) & $1,328.8$ & 5.5 & 5.3 & 4.7 & 9.1 & 19.1 \\
\hline $\begin{array}{l}\text { Population (in percent of world } \\
\text { population) }{ }^{1)}\end{array}$ & 15.46 & 0.06 & 0.06 & 0.05 & 0.11 & 0.22 \\
\hline GDP (in billion US dollars) ${ }^{2)}$ & $3,424.38$ & 310.26 & 246.16 & 389.01 & 453.19 & 1398.62 \\
\hline $\begin{array}{l}\text { GDP per capita (in thousand US } \\
\text { dollars) }{ }^{2)}\end{array}$ & 2.58 & 56.82 & 46.55 & 49.54 & 82.66 & 58.89 \\
\hline Percent share in world GDP ${ }^{2)}$ & 10.83 & 0.30 & 0.28 & 0.38 & 0.51 & 2.57 \\
\hline \multicolumn{7}{|l|}{ In percent of GDP } \\
\hline Consumption & 49 & 75 & 72 & 61 & 73 & 70 \\
\hline Investment & 40 & 22 & 20 & 21 & 19 & 21 \\
\hline Savings & 65 & 24 & 29 & 39 & 28 & 30 \\
\hline GDP growth rate (in percent) & 11.90 & 1.70 & 4.50 & 3.70 & 2.70 & 3.07 \\
\hline $\begin{array}{l}\text { Foreign reserves (in billion US } \\
\text { dollars) }\end{array}$ & $1,337.0$ & 32.9 & 6.2 & 57.4 & 25.5 & 122.0 \\
\hline $\begin{array}{l}\text { Foreign reserves per capita (in } \\
\text { thousands of US dollars) }\end{array}$ & 1.01 & 6.02 & 1.17 & 12.20 & 2.79 & 6.37 \\
\hline $\begin{array}{l}\text { Foreign reserves in months of } \\
\text { imports }\end{array}$ & 8.59 & 0.33 & 0.03 & 0.50 & 0.02 & 0.21 \\
\hline
\end{tabular}

1) Own estimate from UNSTAT.

2) At current market prices. 
Figure 1. Bank credit to GDP in China and Scandinavia, 1980-2008. Percent

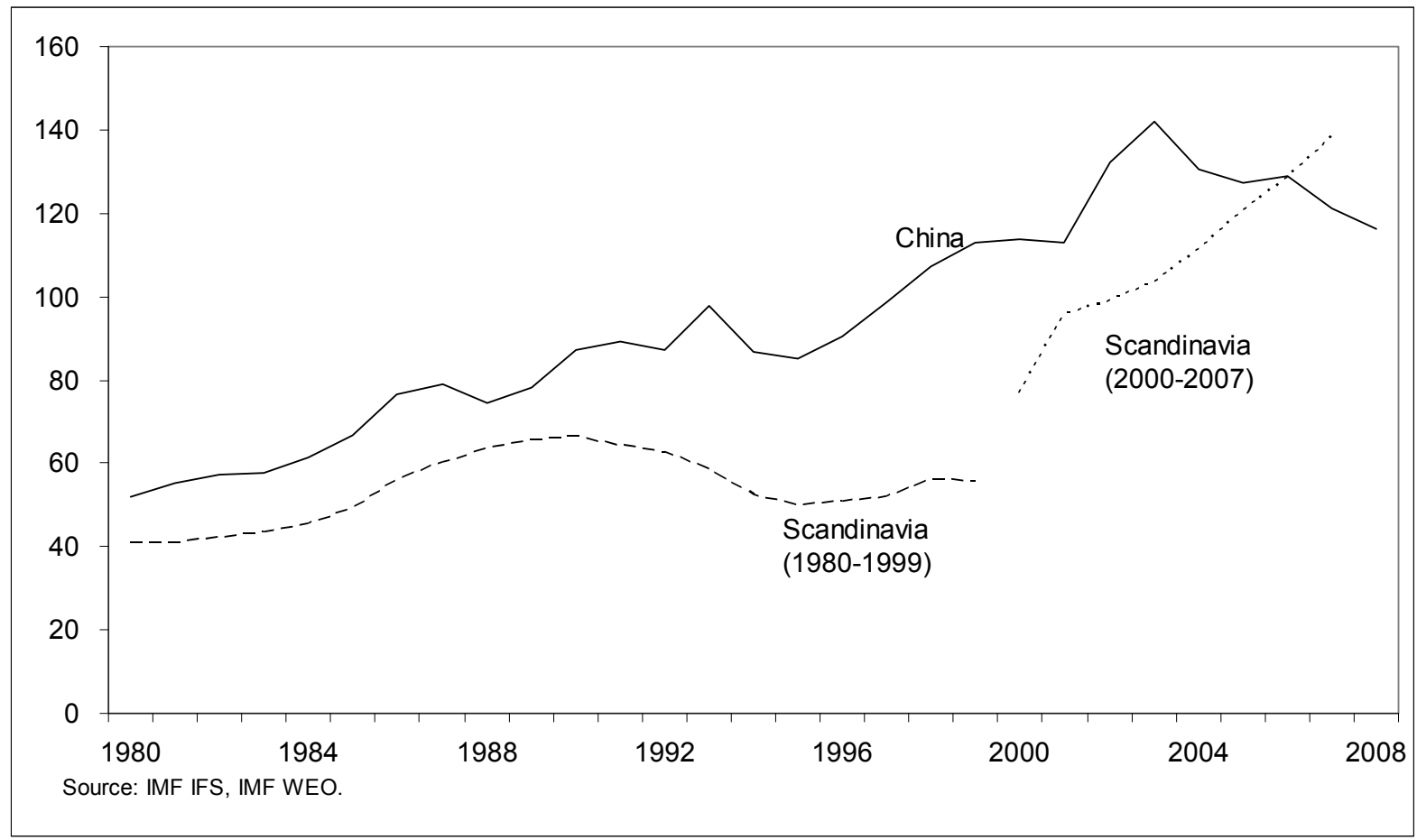

Note: The discontinuity of the series for Scandinavia in 1999-2000 is due to a change in the compilation method for Denmark.

Figure 2. Foreign reserves of China and Scandinavia, 1980-2008. USD billion

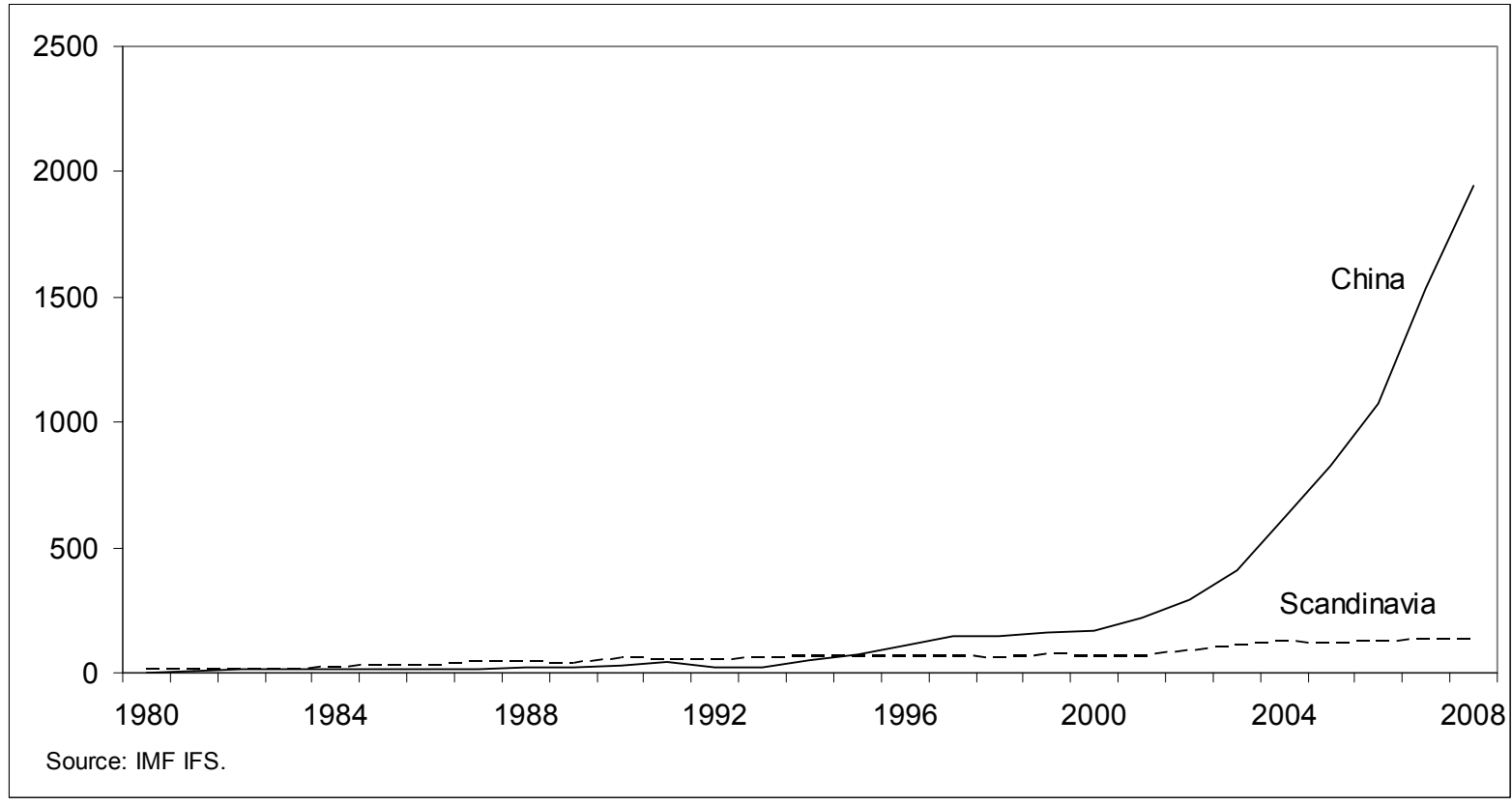


Figure 3. Bank loans to GDP among the Nordics, 1970-1999. Percent of GDP

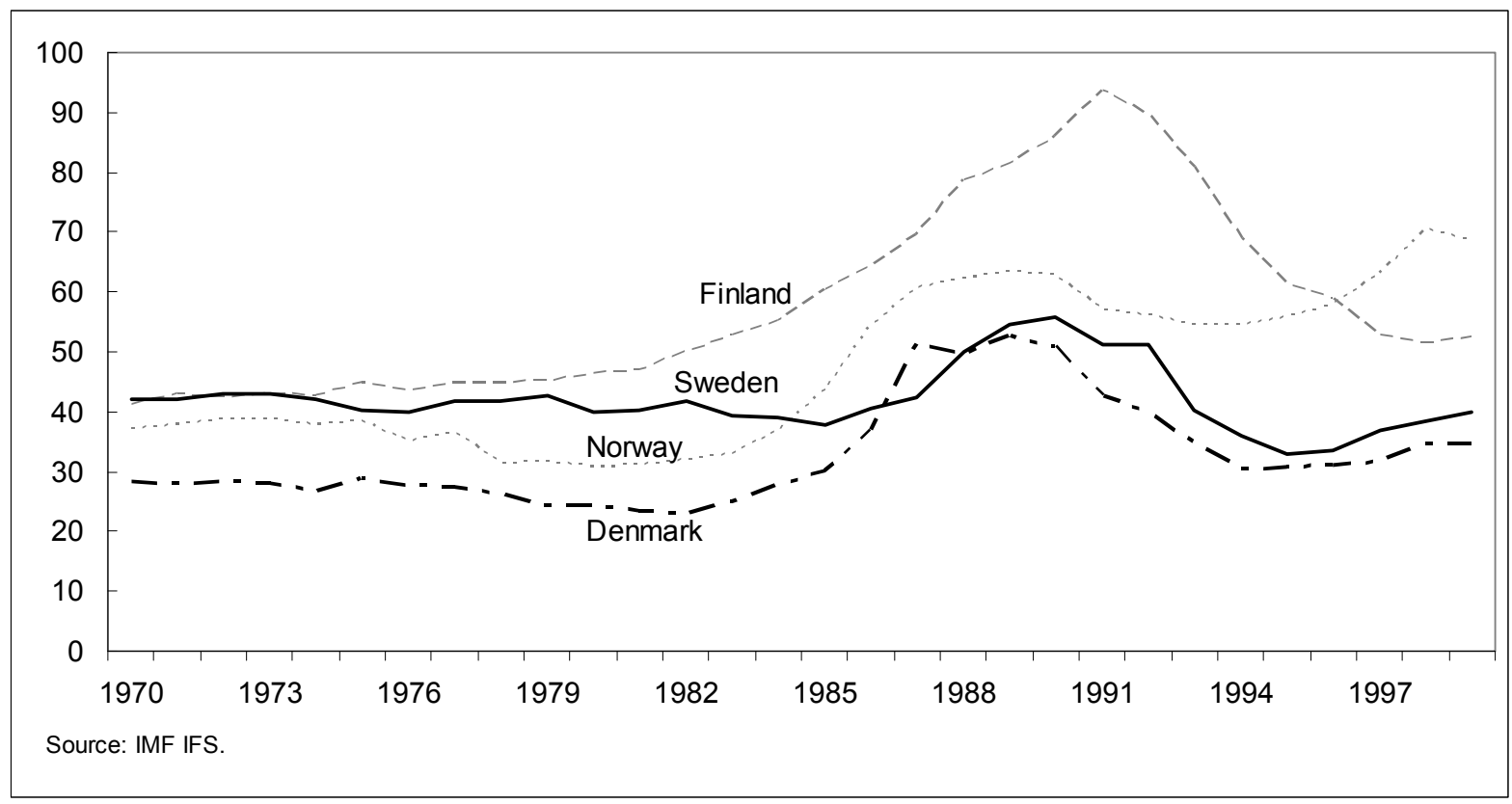

Figure 4. Real after-tax interest rates in Finland and Sweden, 1970-2000. Percent

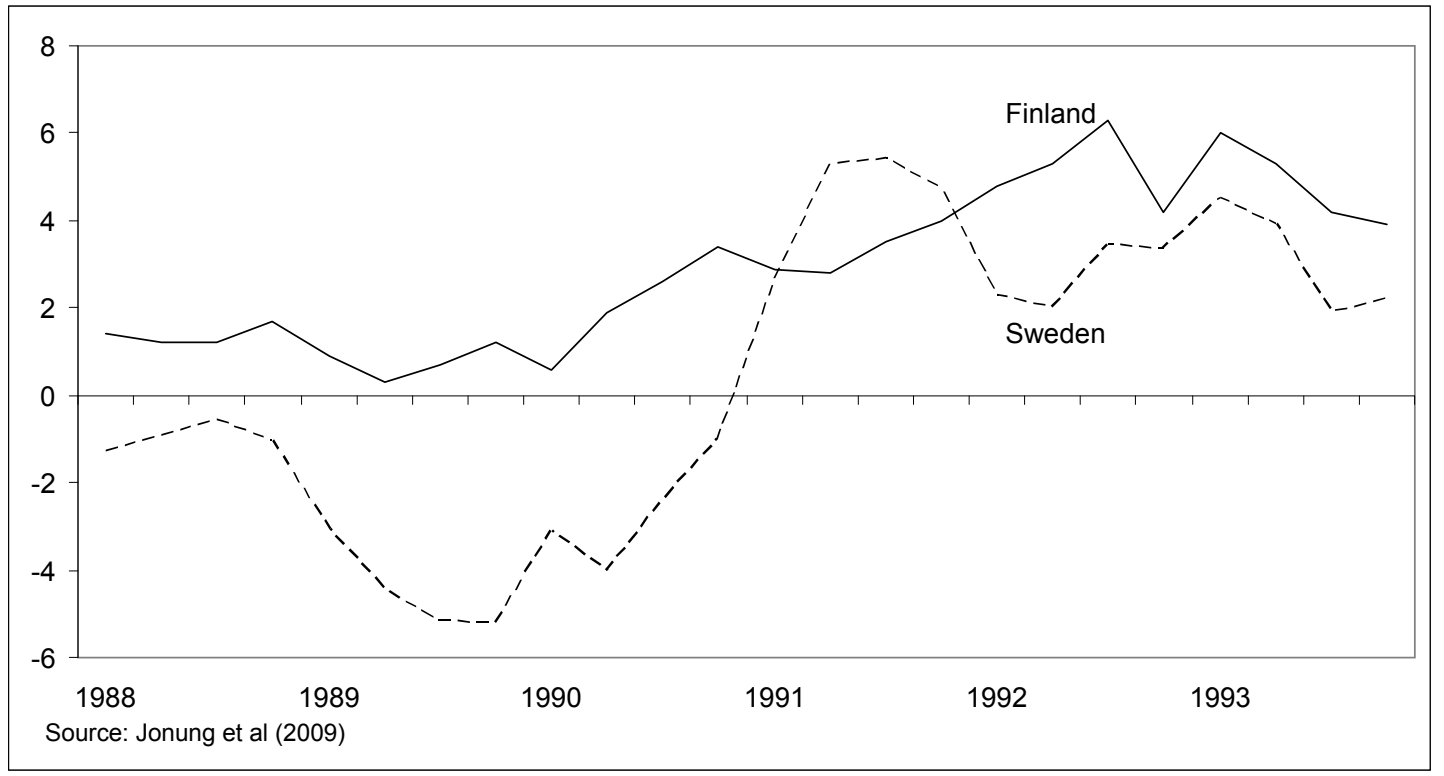


Figure 5. Real GDP growth among the Nordics, 1980-2000. Percent per year

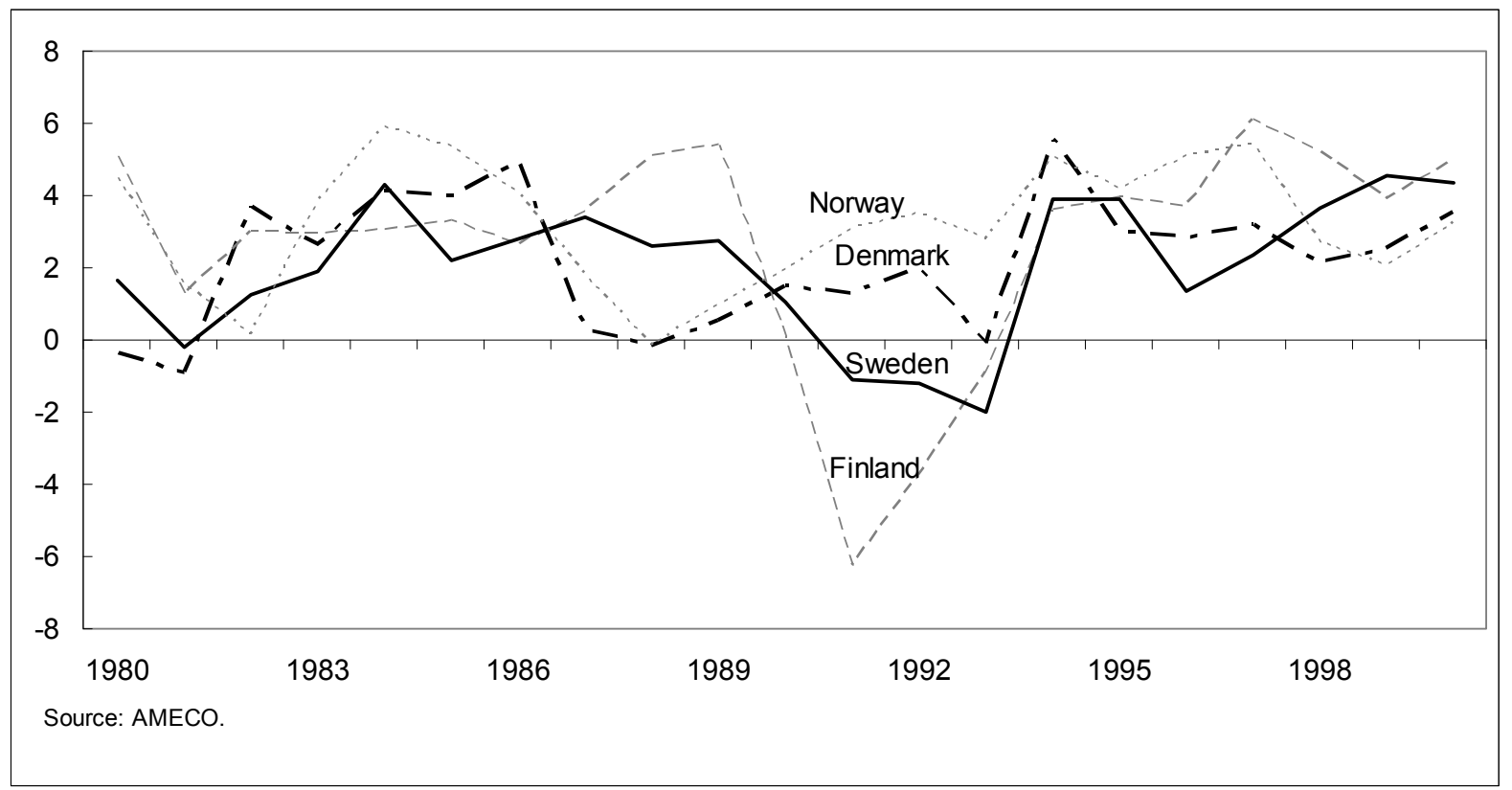

Figure 6. Relative per capita GDP China/Scandinavia, 1980-2014. Percent

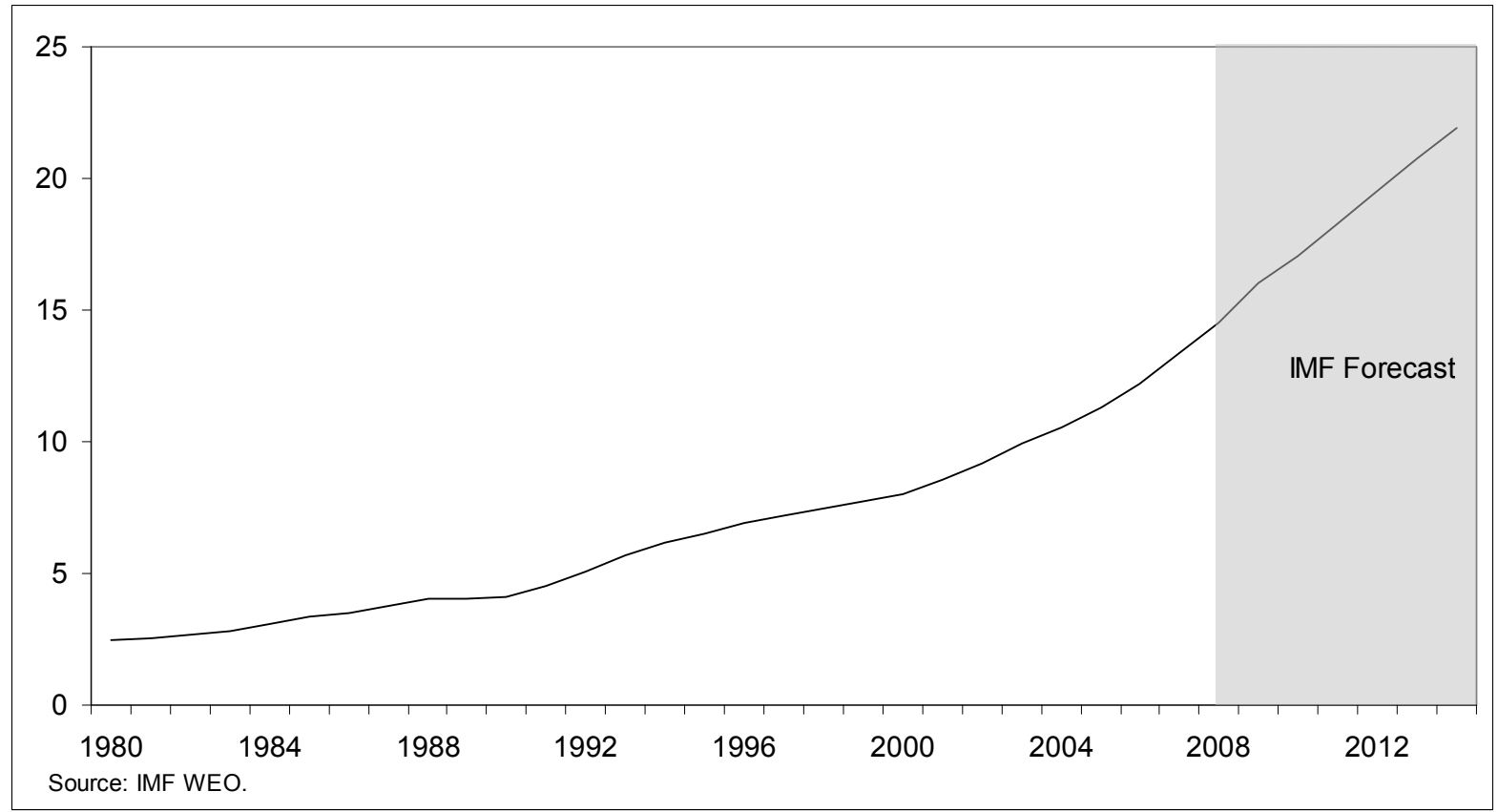

Note: Scandinavia $=100$ in PPP terms. 
Figure 7. Budget deficit as a share of GDP among the Nordics, 1980-2008. Percent

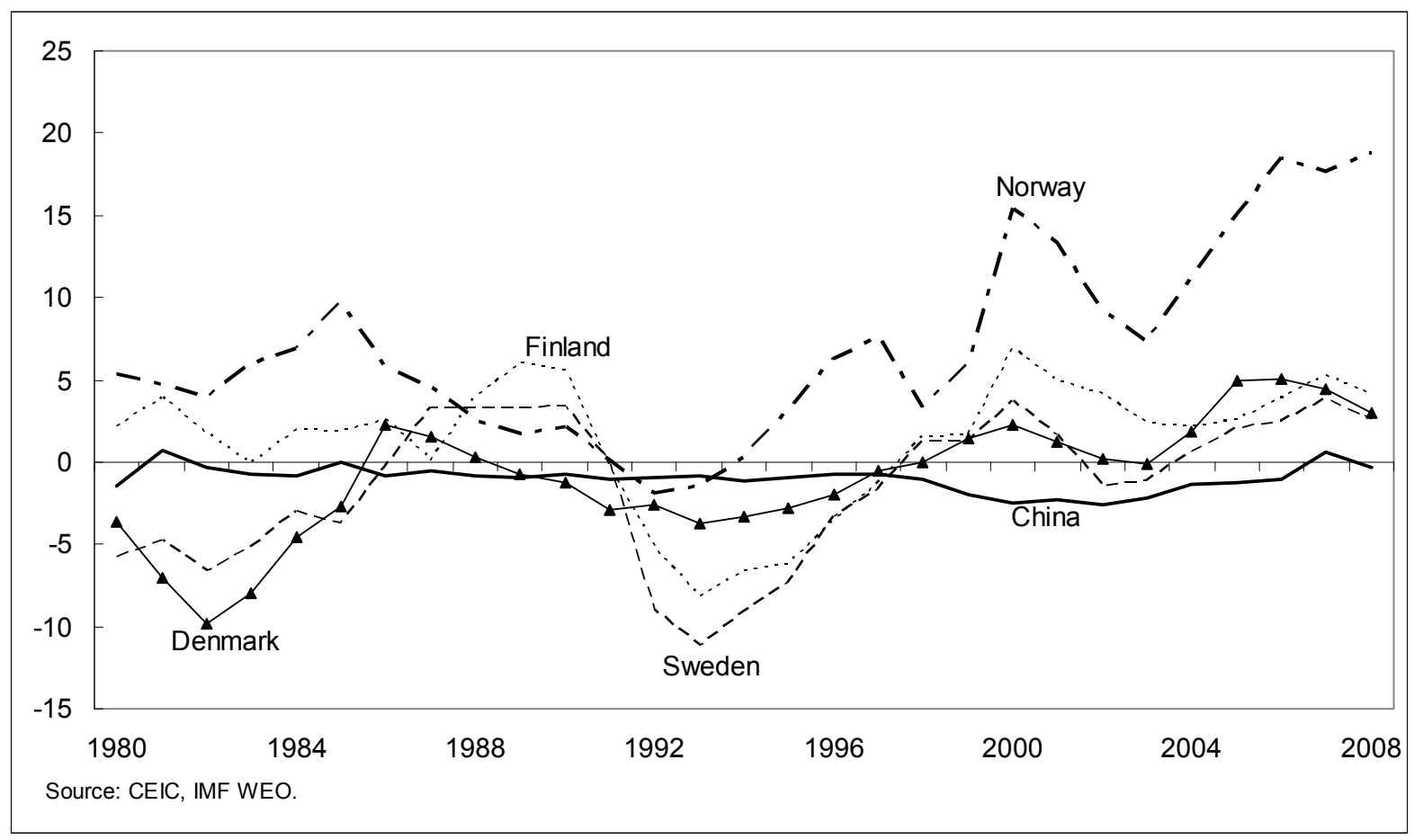

Figure 8. Stock market capitalization in China and Scandinavia, 1980-2007. Percent of GDP

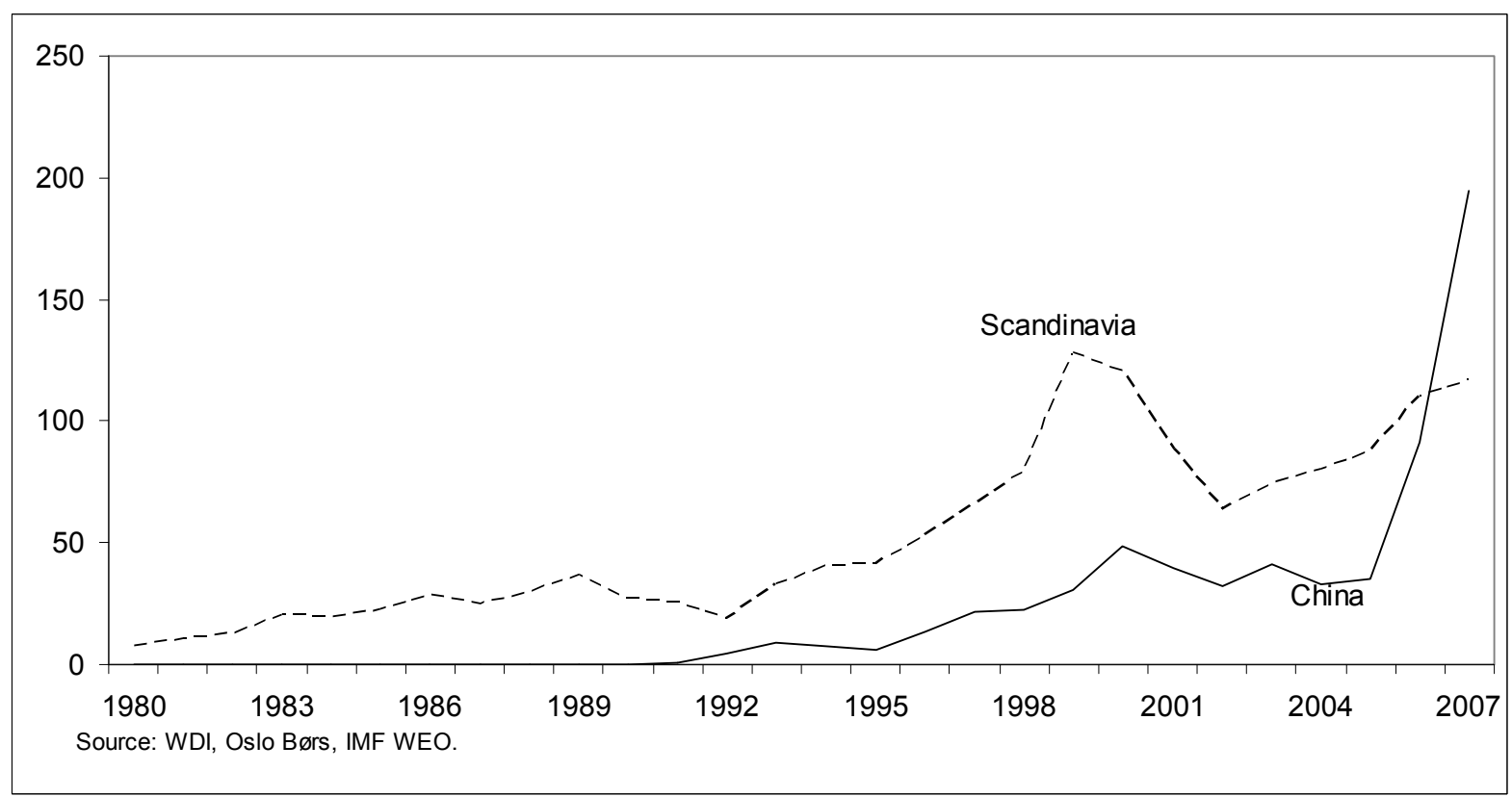


Figure 9. Lending-deposit rate spread in China and Scandinavia, 1980-2008. Percent

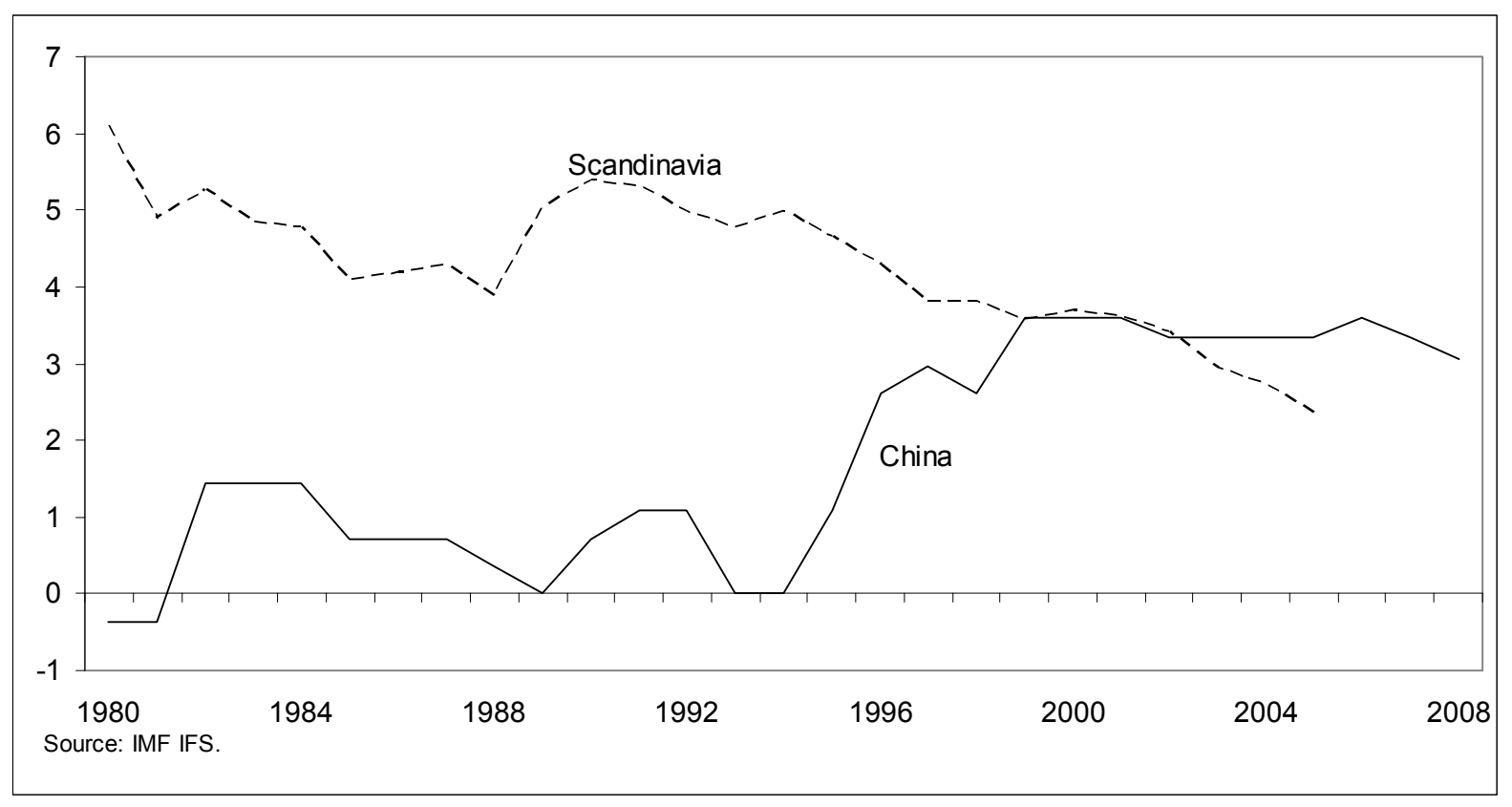

Figure 10. Exports to GDP in China and Scandinavia, 1982-2007. Percent

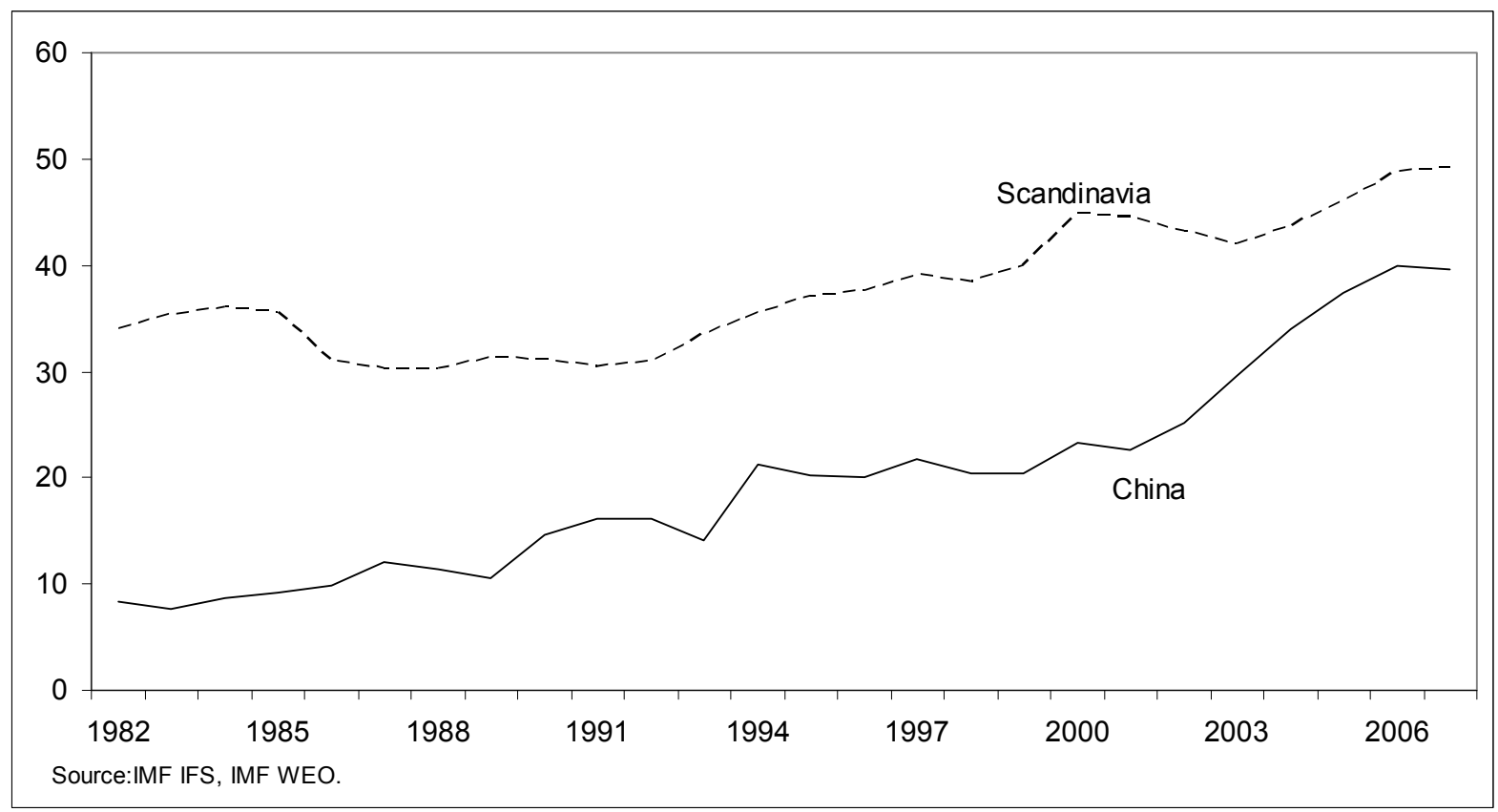


Figure 11. Foreign assets of the banking system to GDP in Scandinavia and China, 1985-2008. Percent

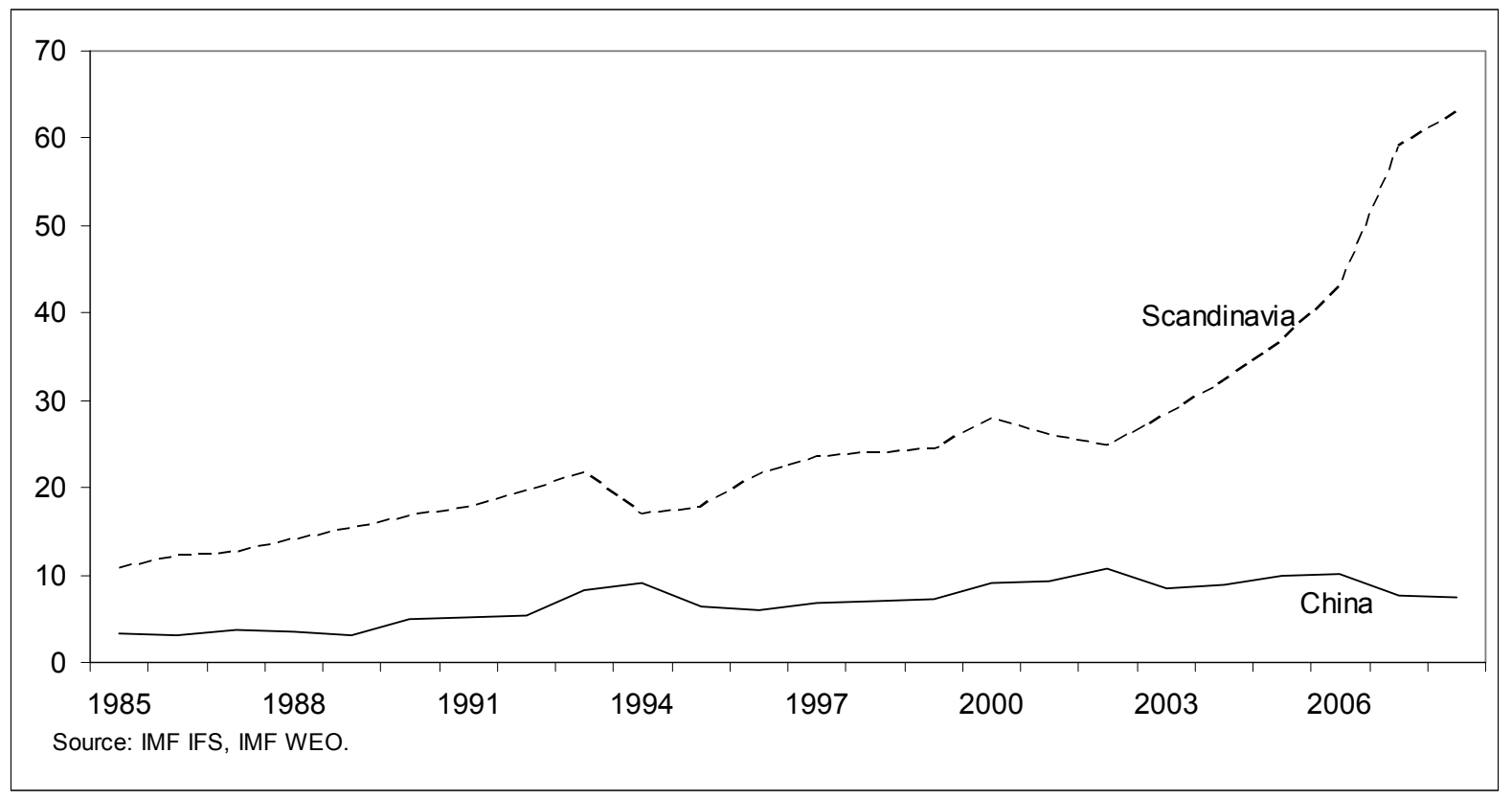

Figure 12. Foreign liabilities of the banking system to GDP in Scandinavia and China, 19802008. Percent

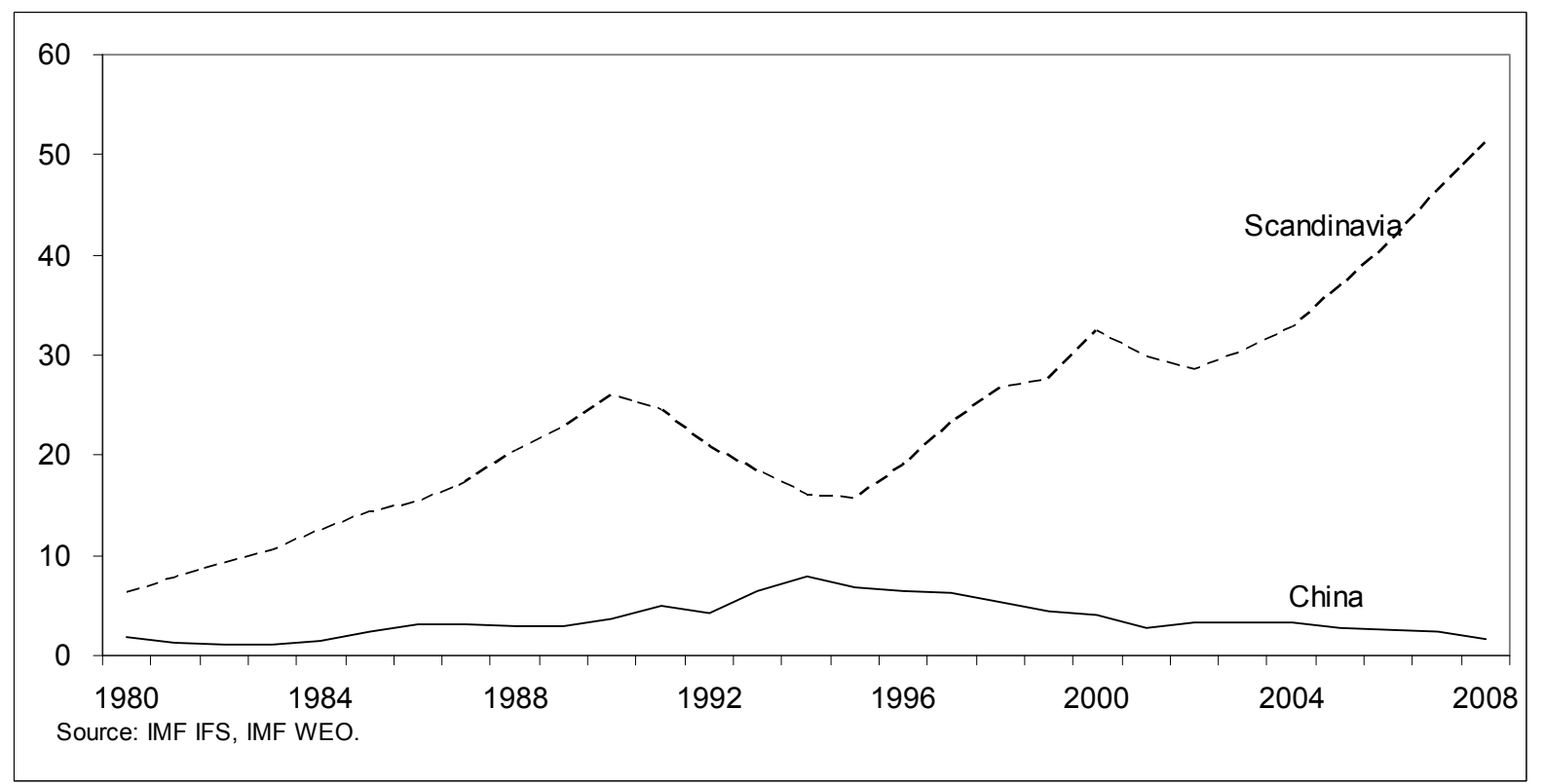


Figure 13. Inward FDI to GDP in Scandinavia and Sweden, 1982-2007. Percent

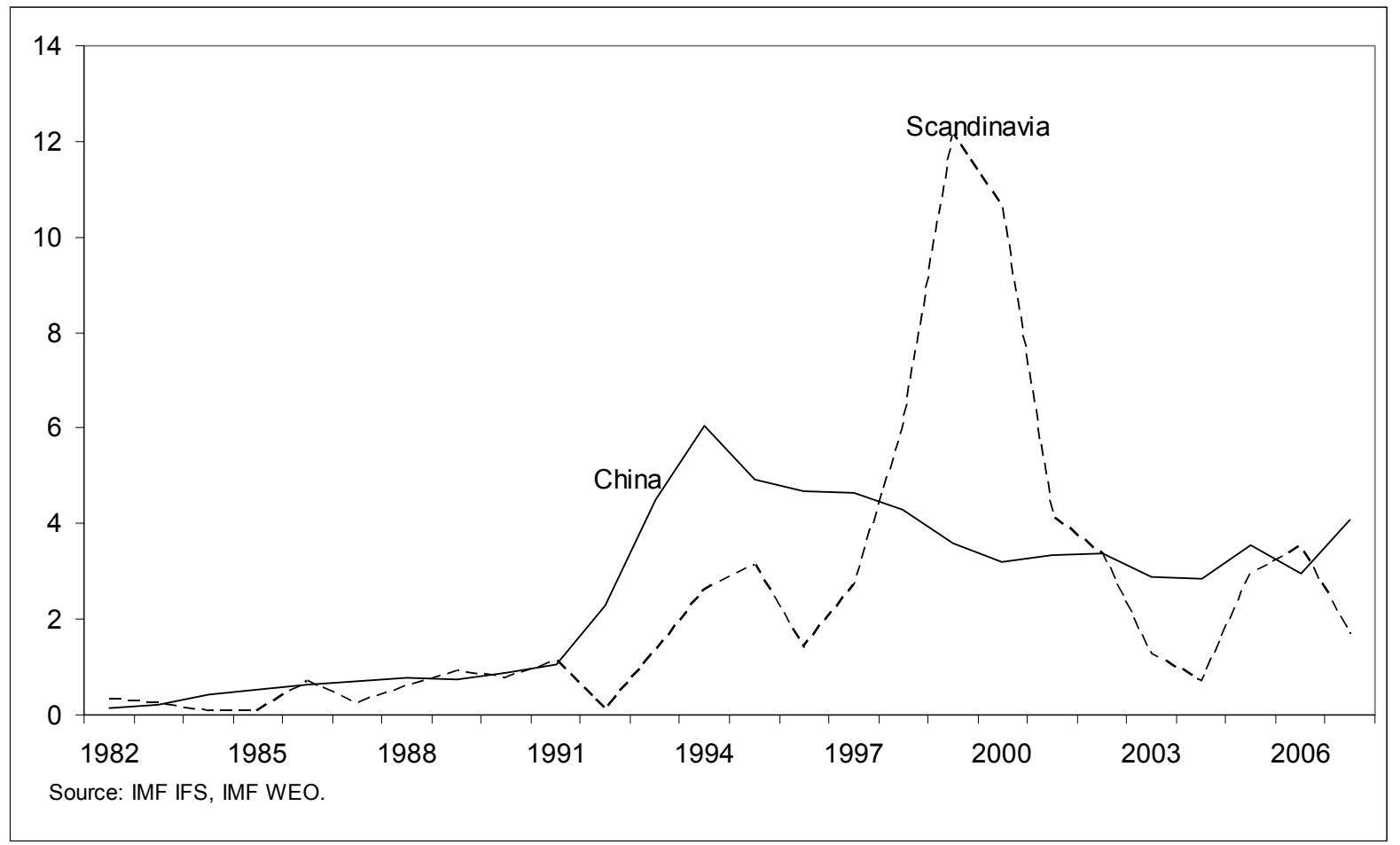

Figure 14. Outward FDI to GDP in Scandinavia and China, 1982-2007. Percent

\begin{tabular}{|lllllllll|}
\hline & 1989 & 1991 & 1994 & 1997 & 2000 & 2003 & 2006 \\
\hline
\end{tabular}

